\title{
Molecular phylogeny of the genus Rotylenchus (Nematoda, Tylenchida) and description of a new species
}

\author{
Nicola Vovlas, Sergei A. Subbotin, Alberto Troccoli, Gracia liébanas \& Pablo Castillo
}

Submitted: 10 January 2008

Accepted: 6 March 2008

doi:10.1111/j.1463-6409.2008.00337.x
Vovlas, N., Subbotin, S. A., Troccoli, A., Liébanas, G. \& Castillo, P. (2008). Description of Rotylenchus montanus sp. $\mathrm{n}$. and recognition of $R$. jaeni comb. $\mathrm{n}$. as a separate species with approaches to molecular phylogeny of the genus Rotylenchus (Nematoda, Tylenchida). Zoologica Scripta, 37, 521-537.

A description of a new species of plant parasitic nematodes of the genus Rotylenchus from the family Hoplolaimidae is given and a recognition of Rotylenchus jaeni comb. n., previously known as subspecies R. magnus jaeni, as separate species is proposed. Rotylenchus montanus sp. $\mathrm{n}$. is characterized by a hemispherical lip region with six rarely seven annuli, stylet 33-37 $\mu \mathrm{m}$, female tail rounded, regularly annulated tip with 12-18 annuli and phasmid located 2-9 annuli anterior to anus. Rotylenchus montanus sp. $\mathrm{n}$. is close to species of the monosexual group $R$. arsenjevi, $R$. corsicus, $R$. fragaricus, $R$. helicus, $R$. indorobustus and $R$. neorobustus, by a number of specific characteristics resulting from its specific matrix code: A5, B1, C1, D4, E2, F2, G3, H2, I2, J2, K2. Molecular characterization of $R$. montanus sp. $\mathrm{n}$. and other Rotylenchus species are provided using D2-D3 expansion segments of 28S and the ITS1 of rRNA genes. The D2-D3 of $28 \mathrm{~S}$ rRNA and the ITS1-rRNA sequences of $R$. montanus sp. $\mathrm{n}$. differed in one nucleotide and in 16-20 nucleotides from those of an unidentified Rotylenchus species from Russia, respectively. Molecular analysis of populations of R. magnus and R.jaeni comb. n. demonstrated differences in the D2-D3 and the ITS1-rRNA sequences. These genetic differences together with some minor morphological characters support that both subspecies should be considered as two cryptic sibling species and warranted their elevation to species rank. The result of phylogenetic analysis of Hoplolaimidae for 45 sequences of the D2 and D3 expansion regions of 28S rRNA gene using Bayesian inference analysis under the complex model is presented. Phylogenetic tree of Rotylenchus species represents seven moderate to highly supported lineages. Grouping of Rotylenchus species within other hoplolaimids and analysis of phylogenetic relationships within the genus Rotylenchus using the ITS1 of rRNA gene sequences are also discussed.

Corresponding author: Pablo Castillo, Instituto de Agricultura Sostenible (IAS), Consejo Superior de Investigaciones Cientificas (CSIC), Apdo.4084, 14080 Córdoba, Spain.E-mail:pcastillo@ias.csic.es Nicola Vovlas, Istituto per la Protezione delle Piante (IPP), Sezione di Bari, Consiglio Nazionale delle Ricerche (C.N.R),Via G. Amendola 165/A, 70126 Bari, Italy.E-mail: n.vovlas@ba.ipp.cnrit Sergei A. Subbotin, Plant Pest Diagnostic Center, California Department of Food and Agriculture, 3294 Meadowview Road, Sacramento, CA 95832-1448, USA; and Center of Parasitology of A.N. Severtsov Institute of Ecology and Evolution of the Russian Academy of Sciences, Leninskii Prospect 33, Moscow, 117071, Russia. E-mail: subbotin@ucr.edu

Alberto Troccoli, Istituto per la Protezione delle Piante (IPP), Sezione di Bari, Consiglio Nazionale delle Ricerche (C.N.R.),Via G. Amendola 165/A, 70126 Bari, Italy.E-mail: a.troccoli@ba.ipp.cnr.it Gracia Liébanas, Departamento de Biología Animal, Vegetal y Ecología, Universidad de Jaén, Campus 'Las Lagunillas's/n, Edificio B3, 23071, Jaén, Spain. E-mail: gtorres@ujaen.es 


\section{Introduction}

The phylum Nematoda Rudolphi 1808 tends to be greatly conserved in gross morphology which makes species identification a very difficult task. Since species of nematodes has traditionally been based on the morphological or typological species concept, molecular techniques have recently shown that many presumed monospecific species are in fact siblings or cryptic species genetically distinct but sharing common morphological diagnostic characters (Anderson et al. 1998; Blouin 2002; Subbotin et al. 2003; Ye et al. 2004; Oliveira et al. 2006; Tandingan De Ley et al. 2007). Nevertheless, the nematode species concept has been recently discussed, suggesting that delimitation of species should be based either mainly in an amalgamation of the phylogenetic species concept and evolutionary species concept (Adams 1998; Nadler 2002) or principles of polyphasic taxonomy, which assembles and assimilates all available data and information (phenotypic, genotypic and phylogenetic) used for delimiting taxa at all levels (Vandamme et al. 1996; Subbotin \& Moens 2006). In this paper, nematode species is considered not only as an independent evolutionary lineage, because phylogenetic analysis is one objective evolutionary method for analysing character-state data (e.g. nucleotide data) to test the hypothesis of lineage independence (Adams 1998), but also as a group of organisms distinguishing from others by phenotypical, genotypical and biological peculiarities.

The genus Rotylenchus Filipjev 1936 belongs to Hoplolaimidae Filipjev 1934, a family which also contains agricultural and economically important genera such as Helicotylenchus Steiner 1945, Hoplolaimus Von Daday 1905, Rotylenchulus Lindford \& Oliveira 1940 and Scutellonema Andrássy 1958. In their recent monograph, Castillo \& Vovlas (2005) recognized 92 valid species and two subspecies of Rotylenchus magnus Zancada 1985, which confirm the previously referred conserved morphology. All the known Rotylenchus spp. are obligate plant parasites of a wide range of wild and cultivated plants and are closely associated with plant roots. They are migratory ectoparasites and browse on the surface of roots. As migratory ectoparasites do not enter the plant root, the damage they cause is usually limited to necrosis of those cells penetrated by stylet. However, species with longer stylets (such as, Rotylenchus cazorlaensis Castillo \& Gómez Barcina 1988, Rotylenchus magnus magnus (Zancada 1985) Castillo et al. 1994, Rotylenchus magnus jaeni Castillo et al. 1994 and Rotylenchus robustus (de Man 1876) Filipjev 1936) penetrate the tissues more deeply, thereby killing more cells and causing more extensive damage to the root.

The large number of species recognized within the genus Rotylenchus complicated the identification process and have required the construction of tabular and dichotomous keys to enable pragmatic morphological identification (Castillo $\&$ Vovlas 2005). These keys are based on a combination of major and supplementary characters (such as lip annulation, lip shape, lateral field areolation, body longitudinal striation, stylet length, dorsal pharyngeal gland outlet, pharyngeal gland overlap, tail shape, vulva position, presence of males and phasmid position). Furthermore, a phylogenetic study within Hoplolaimidae has been carried out based on the D2 and D3 expansion regions of the 28S rRNA gene, providing initial insight toward resolving phylogenetic relationships among hoplolaimids, and demonstrating paraphyly in the majority rule consensus tree (Subbotin et al. 2007). However, surprisingly, molecular analysis revealed almost identical sequences for Rotylenchus goodeyi Loof \& Oostenbrink 1958 and Rotylenchus laurentinus Scognamiglio \& Talamé 1973 suggesting that they are very closely related or co-specific taxa. This grouping clearly contradicts diagnostic morphological differences with respect to numbers of lip annuli, cuticular patterns, stylet length, position of the dorsal gland orifice and vulva position (Castillo \& Vovlas 2005).

Nematode surveys in agricultural and natural environments in Northern Italy (apple orchards in Val di Non, Trento province, and in unidentified grasses in Cervinia, Aosta province, respectively) revealed high soil infestations by a monosexual population of a Rotylenchus species, which do not fit with any description of the 92 nominal species in the genus (Castillo \& Vovlas 2005). Detailed observations with light and scanning electron microscopy (SEM), and with molecular characterization, indicated that these specimens should be assigned to a new species. In addition, well morphologically characterized Rotylenchus populations from Italy, Spain and United States were collected to carry out molecular analyses which may clarify the phylogeny of the genus. Furthermore, three Spanish populations belonging to two subspecies of $R$. magnus were studied under SEM and molecular analyses to confirm their taxonomic status. The phylogenetic analysis includes 36 populations of one new, 18 known and four unidentified species of the genera Rotylenchus, Helicotylenchus, Scutellonema, Hoplolaimus and Peltamigratus Sher 1964, and three outgroup taxa from the genera Aglenchus Andrássy 1954, Coslenchus Siddiqi 1978 and Basiria Siddiqi 1959.

The objectives of this study were: (i) to carry out a detailed morphological and morphometrical characterization of the new taxon herein described as $R$. montanus sp. n.; (ii) to make molecular comparison of $R$. montanus sp. $\mathrm{n}$ and closely related unidentified Rotylenchus species from Russia using the ITS1 of rRNA gene sequences; (iii) to estimate sequence diversity between populations, subspecies and species of the genus using sequences of the D2-D3 expansion segments of the $28 \mathrm{~S}$ nuclear ribosomal RNA gene and the ITS1 of rRNA; (iv) to carry out a phylogenetic analysis within Hoplolaimidae based on sequences of the D2-D3 of the 28S rRNA gene with Bayesian analysis using the complex model of evolution considering secondary structure information; and (v) to present 
Table 1 Rotylenchus species, subspecies and populations used in the present study*.

\begin{tabular}{|c|c|c|c|c|c|c|}
\hline \multirow[b]{2}{*}{ Species } & \multirow[b]{2}{*}{ Locality } & \multirow[b]{2}{*}{ Host } & \multicolumn{2}{|l|}{ GenBank accession no. } & \multirow[b]{2}{*}{ Study $\dagger$} & \multirow[b]{2}{*}{ Source } \\
\hline & & & D2-D3 of 285 rRNA & ITS-rRNA & & \\
\hline Rotylenchus agnetis & Potenza, Italy & Ruscus aculeatus (butcher's broom) & EU280795 & - & SD & N. Vovlas \\
\hline R. cazorlaensis & Cazorla, Spain & Quercus faginea (Portuguese oak) & EU280793 & EU373668, EU373669 & SD, SITS & P. Castillo \\
\hline R. cazorlaensis & Cazorla, Spain & Quercus rotundifolia (oak) & EU280792 & EU373670, EU373671 & SD, SITS & P. Castillo \\
\hline R. eximius & Huelva, Spain & Olea europaea sp. sylvestris (wild olive) & DQ328741 & - & $\mathrm{M}, \mathrm{SD}$ & $\begin{array}{l}\text { P. Castillo, } \\
\text { Subbotin et al. (2007) }\end{array}$ \\
\hline R. eximius & Brindisi, Italy & Pistacia lentiscus (lentisc) & EU280794 & EU373663, EU373664 & SD, SITS & N. Vovlas \\
\hline R. goodeyi & Cádiz, Spain & Olea europaea sp. sylvestris (wild olive) & DQ328756 & - & $M, S D$ & $\begin{array}{l}\text { P. Castillo, } \\
\text { Subbotin et al. (2007) }\end{array}$ \\
\hline R. incultus & Bollullos, Spain & Vitis vinifera (grapevine) & EU280797 & - & $\mathrm{M}, \mathrm{SD}$ & P. Castillo \\
\hline R. incultus & Niebla, Spain & Vitis vinifera (grapevine) & EU280796 & EU373672, EU373673 & M, SD, SITS & P. Castillo \\
\hline R. laurentinus & Torre Canne, Italy & Pistacia lentiscus (lentisc) & DQ328757 & - & SD & $\begin{array}{l}\text { N. Vovlas, } \\
\text { Subbotin et al. (2007) }\end{array}$ \\
\hline R. laurentinus & Zahara, Spain & Pistacia lentiscus (lentisc) & EU280798 & EU373666, EU373667 & M, SD, SITS & P. Castillo \\
\hline R. jaeni comb. $\mathrm{n}$. & Santa Elena, Spain & Quercus suber (cork tree) & EU280791 & EU373661, EU373662 & SD, SITS & P. Castillo \\
\hline R. magnus & Lubia, Spain & Quercus robur (pedunculate oak) & EU280790 & EU373659, EU373665 & SD, SITS & P. Castillo \\
\hline R. magnus & Arévalo, Spain & Ilex aquifolium (holly) & EU280789 & EU373660, EU373676 & SD, SITS & P. Castillo \\
\hline R. montanus sp. $\mathrm{n}$. & Trentino, Italy & Malus domestica (apple) & DQ328743 & EU280800; EU280801 & M, SD, SITS & $\begin{array}{l}\text { N. Vovlas, } \\
\text { Subbotin et al. (2007) }\end{array}$ \\
\hline R. robustus & Michigan, USA & Unknown & EU280788 & - & SD & G. Bird \\
\hline R. uniformis & Bruges, Belgium & Unknown & DQ328735, DQ328736 & - & SD & Subbotin et al. (2007) \\
\hline R. uniformis & Ghent, Belgium & Unknown & DQ328738 & - & SD & Subbotin et al. (2007) \\
\hline R. uniformis & Poppel, Belgium & Unknown & DQ328739, DQ328740 & - & SD & Subbotin et al. (2007) \\
\hline R. uniformis & Elst, the Netherlands & Unknown & DQ328737 & - & SD & Subbotin et al. (2007) \\
\hline R. unisexus & Seville, Spain & Citrus aurantium (citrus) & EU280799 & EU373674, EU373675 & M, S, SITS & P. Castillo \\
\hline Rotylenchus sp. 1 & Moscow, Russia & Unknown & DQ328742 & EU280802 & SD, SITS & Subbotin et al. (2007) \\
\hline
\end{tabular}

*A new sequence of Scutellonema brachyurus (EU280787) from Mt. Dora, Florida, USA, Sanseveria sp. was also included in this study. Taxonomic categories referred to in this work are those of Castillo \& Vovlas (2005).

tM, Morphological and/or morphometrical study; SD, sequence of the D2-D3 of 28S rRNA gene, SITS, sequence of the ITS1 of rRNA gene.

phylogenetic relationships with the genus Rotylenchus based on analysis of the ITS1 of rRNA gene sequences.

\section{Materials and methods}

\section{Nematode populations and morphological studies}

Nematode populations of the new species used in this study were obtained from apple orchards in Val di Non, Trento province, and in pastures at Cervinia, Aosta province (Northern Italy), and were collected with a shovel from the upper $30 \mathrm{~cm}$ of soil on December 2005 by the first author. In addition, two Italian population of Rotylenchus eximius Siddiqi 1964 and Rotylenchus agnetis Szczygiel 1968 and nine Spanish populations belonging to five species and two subspecies of the genus Rotylenchus were collected from natural and cultivated environments and studied morphometrically and/or under SEM observations (Table 1).

Specimens used in this study were extracted from soil samples with magnesium sulphate centrifugal flotation method (Coolen 1979). Specimens for light microscopy were killed by gentle heat, fixed in a solution of $4 \%$ formaldehyde $+1 \%$ propionic acid, and processed to pure glycerine using Seinhorst's (1966) method. Specimens were examined using a Polyvar compound microscope (Reichert-Jung, Milton Keynes, UK) equipped with differential interference contrast optics up to $\times 1000$ magnification. Measurements were done using a camera lucida attached to a light microscope and, unless indicated otherwise in the text, all measurements were made in relation to the nematode body and expressed in micrometres $(\mu \mathrm{m})$. Morphometric data were processed using STatistix 8.0 (NH Analytical Software, Roseville, $\mathrm{MN}$ ) and expressed as: mean \pm SD (range).

For SEM studies, fixed specimens were dehydrated in a graded ethanol series, critical point dried, sputter-coated with gold and observed with a JEOL JSM-5800 microscope (Abolafia et al. 2002).

For molecular analyses, a list of studied Rotylenchus species, subspecies and populations is given in Table 1 .

\section{DNA extraction, PCR assays and sequencing}

Nematode DNA was extracted from 3 to 15 nematode specimens and transferred to an Eppendorf tube containing $16 \mu \mathrm{L} \mathrm{ddH_{2 }} \mathrm{O}, 2 \mu \mathrm{L} 10 \times$ PCR buffer and $2 \mu \mathrm{L}$ proteinase $\mathrm{K}$ $(600 \mu \mathrm{g} / \mathrm{mL})$ (Promega, Madison, WI) and manually crushed using pipette (Castillo et al. 2003). The tubes were incubated 
at $65^{\circ} \mathrm{C}(1 \mathrm{~h})$ and then at $95^{\circ} \mathrm{C}(15 \mathrm{~min})$. Detailed protocols for PCR, cloning and automated sequencing were as described by Subbotin et al. (2007). The forward D2A (5'-CAAGTAC CGTGAGGGAAAGTTG-3') and reverse D3B (5'-TC GGAAGGAACCAGCTACTA- $3^{\prime}$ ) primers or the forward D2TylenchA (5'-CAAGTACCGTGAGGGAAAGTT-3') and reverse $\mathrm{D} 3 \mathrm{~B}$ were used for amplification and sequencing of the fragment of the 28S rRNA gene. The forward TW81 (5'-GTTTC CGTAGGTGAACCTGC- $3^{\prime}$ ) and the reverse 5.8SM5 (5'-GGCGCAATGTGCATTCGA-3') were used for amplification and sequencing of the ITS1 of the rRNA gene. The newly obtained sequences have been submitted to GenBank database under the numbers indicated in Table 1 for $\mathrm{D} 2$ and D3 expansion regions of $28 \mathrm{~S}$ rRNA and the ITS1 of rRNA gene.

\section{Sequence and phylogenetic analysis}

The ITS1-rRNA sequences of Rotylenchus species were aligned using ClustalX1.83 (Thompson et al. 1997) with default parameters and edited and modified using GenDoc (Nicholas et al. 1997). Secondary structure of D2 and D3 of 28rRNA for new samples was predicted separately for each expansion segments and for each sequence using MFOLD software program v3 <http://www.bioinfo.rpi.edu/ zukerm/> (Zuker 1989). Outgroup taxa for hoplolaimids were selected according to Subbotin et al. (2007). Secondary structures for other published hoplolaimid sequences were obtained from NEMrRNA database (Subbotin et al. 2007). Structures were visualized with PseudoViewer 3 (Han et al. 2002). The D2 and D3 sequences with secondary structure format were aligned separately using the MARNA web server (Siebert \& Backofen 2005) <http://biwww2.informatik.uni-freiburg.de/ Software/MARNA/index.html> based on both the primary and secondary structures. As the default setting, the base deletion was scored 2.0, base mismatch 1.0, arc removing 2.0, arc breaking 1.5 and mismatch 1.8 with ensemble of shaped structures. The ITS and D2-D3 alignments are available from the second author by request. D2 and D3 sequence information on secondary structure, in dot-bracket structure for all species studied here and was deposited in the new online database NEMrRNA <http://www.nemamex.ucr.edu/rna> (Subbotin et al. 2007). The appropriate outgroup taxa for Hoplolaimidae were selected based on result of phylogenetic analysis of the Tylenchida (Subbotin et al. 2006). The ITS sequence for Rotylenchus brevicaudatus Colbran 1962 was obtained from the GenBank (Chen et al. 2006).

Sequence analyses of alignments were performed with PAUP* 4b10 (Swofford 2003). The ITS-RNA alignment and D2-D3 alignment were analysed using maximum parsimony (MP) with PAUP* $4 \mathrm{~b} 10$ and Bayesian inference (BI) with MrBayes 3.0 (Huelsenbeck \& Ronquist 2001) under the GTR + G + I and the complex model, respectively. For MP analysis heuristic search settings included: 10 replicates of random taxon addition, tree bisection-reconnection branch swapping, multiple trees retained, no sleepest descent and accelerated transformation. Robustness of the clades was assessed using the MP bootstrap analysis yielding a bootstrap percentage for each node estimated from 1000 replicates.

SECconverter <http://www.nemamex.ucr.edu/rna $>$ was used to convert $50 \%$ consensus secondary structure in dot-bracket format for stem and loop partitions for MRBAYES command block. The complex model included the doublet model with 16 states of nucleotide doublets for the stem region. It also included the standard model of DNA substitution with four nucleotide states for loops and bulges and a $\Gamma$-distribution (G) of among-site-rate heterogeneity with six rate categories (Ronquist \& Huelsenbeck 2005). Bayesian analysis was initiated with random starting trees and was run with four chains for $1.0 \times 10^{6}$ generations. Two runs were performed. The Markov chains were sampled at intervals of 100 generations. The log-likelihood values of the sample points stabilized after approximately $10^{3}$ generations. After discarding burn-in samples and evaluating convergence, the remaining samples were retained for further analysis. The topologies were used to generate a $50 \%$ majority rule consensus tree. Posterior probabilities (PP) were calculated for appropriate clades.

\section{Description of a new species of Rotylenchus Filipjev 1936 Genus Rotylenchus Filipjev 1936 Rotylenchus montanus sp. n. (Figs 1-3, Tables 2-3)}

Holotype. Female extracted from soil samples collected from apple orchards in Val di Non, Trento province, Italy, by $\mathrm{N}$. Vovlas, mounted in pure glycerine and deposited in the nematode collection at Istituto per la Protezione delle Piante (IPP) of Consiglio Nazionale delle Ricerche (C.N.R.), Sezione di Bari, Bari, Italy (collection number IPP-Rm-07).

Paratypes. Female paratypes extracted from soil samples collected from apple orchards in Val di Non, Trento province, Italy, and additional female paratypes collected in Cervinia, Aosta province (at $2000 \mathrm{~m}$ of altitude) Northern Italy, at the edges of the Blue lake, associated with unidentified grasses were deposited in the following nematode collections: Istituto per la Protezione delle Piante (IPP) of Consiglio Nazionale delle Ricerche (C.N.R.), Sezione di Bari, Bari, Italy (collection numbers IPP-Rm-01 to IPP-Rm-07 and IPP-Rm-09); Instituto de Agricultura Sostenible (IAS), Consejo Superior de Investigaciones Científicas (CSIC), Córdoba, Spain (collection numbers IPP-Rm-011 to IPP-Rm-015); University of California, Davis; USDA Nematode collection, Beltsville, Maryland (collection number IPP-Rm-08), and Nematode collection of the Department of Nematology, Landbouwhogeschool, Wageningen, the Netherlands (collection number IPP-Rm-010). 


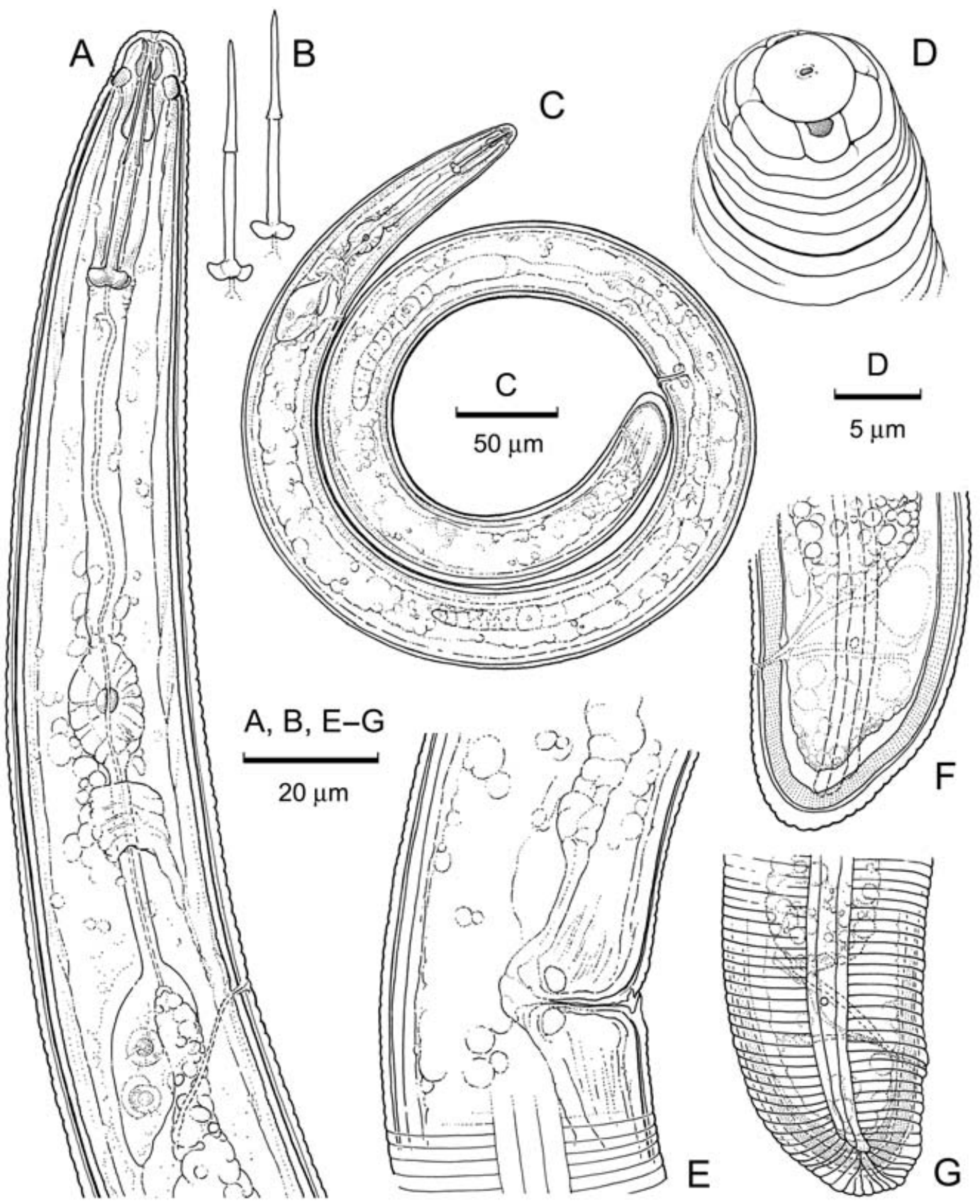

Fig. 1 A-G. Line drawings of Rotylenchus montanus sp. n. -A. Pharyngeal region; —B. Detail of stylet; -C. Whole body; —D. Detail of lip region showing oral disc; - E. Vulval region; -F,G. Female tail.

Etymology. The species name is in accordance with the habitat (mountains altitude of both sampling localities) from Latin montanus $-a,-u m=$ inhabiting the mountain.

Diagnosis. Rotylenchus montanus sp. $\mathrm{n}$. is a monosexual species of the genus Rotylenchus assigned to the monosexual species group having rounded female tail and more than $30 \mu \mathrm{m}$ of stylet length (Castillo \& Vovlas 2005). It is characterized mainly by a hemispherical lip region with six, rarely seven, annuli, stylet length of $33-37 \mu \mathrm{m}$, vulva position at $53-58 \%$, rounded tail with 12-18 annuli, and a specific D2-D3 sequence (GenBank accession number DQ328741, Subbotin et al. 2007). 


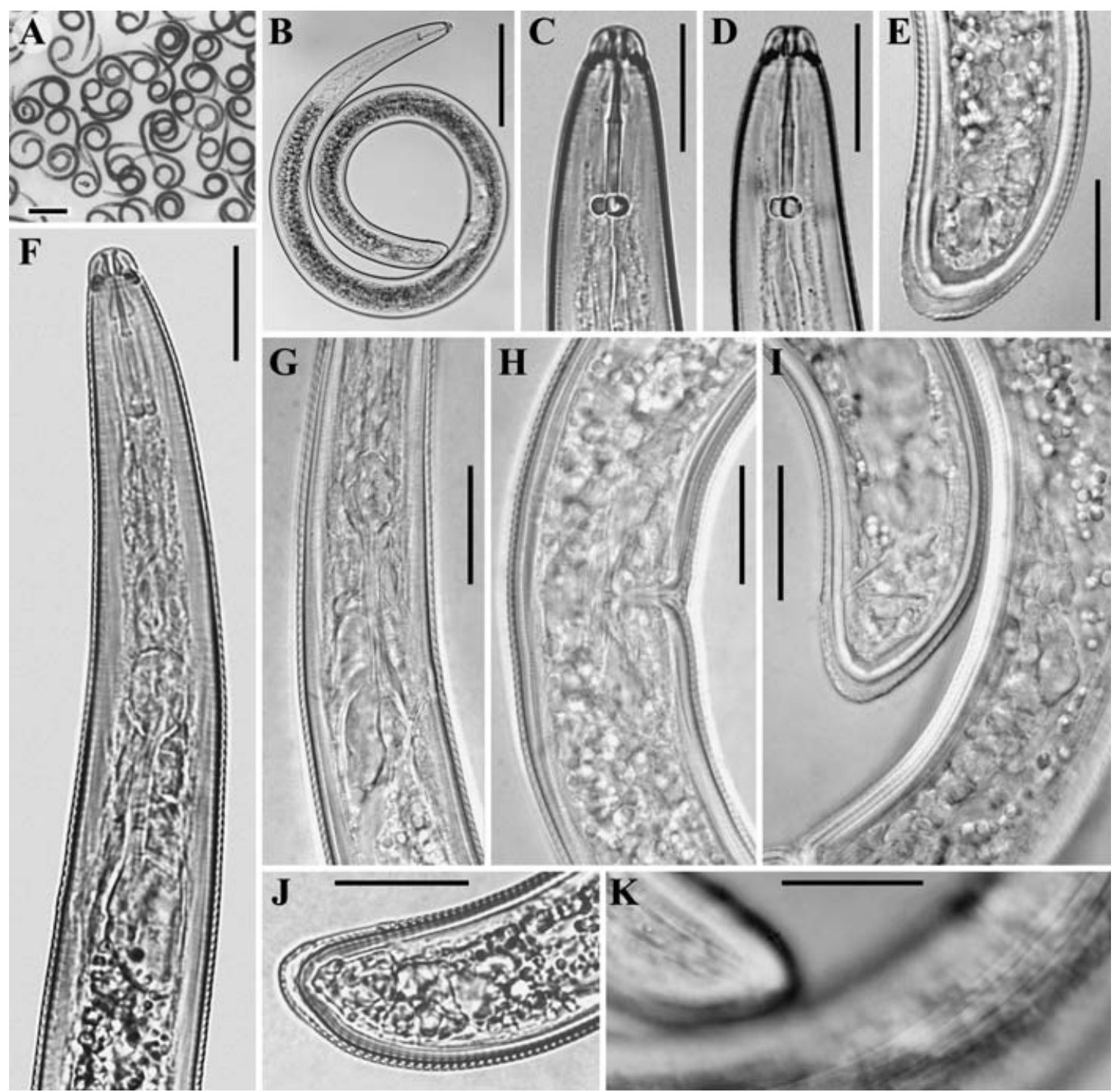

Fig. 2 A-K. Photomicrographs of Rotylenchus montanus sp. n. -A,B. Whole body; -C,D. Female lip region; -E,I,J. Female tail; —F,G. Female pharyngeal region; - H. Vulval region; -K. Tail showing phasmids and lateral fields. (Scale bars: A, $250 \mu \mathrm{m}, \mathrm{B}, 100 \mu \mathrm{m}$; C-K, $25 \mu \mathrm{m}$ ).

\section{Description}

Female (holotype). $\mathrm{L}=1071$; maximum body width $=40.5$; anal body width $=26$; stylet length $=34$; dorsal pharyngeal gland orifice $(\mathrm{DGO})=4.5$; pharynx (to middle of valve $)=148.5$; pharynx $($ total length $)=173$; pharyngeal overlap $=24$; excretory pore from anterior end $=149$; tail length $=16.5 ; \mathrm{V} \%=54$; $\mathrm{G}_{1}=17 ; \mathrm{G}_{2}=18 ; \mathrm{a}=26.3 ; \mathrm{b}=7.2 ; \mathrm{b}^{\prime}=6.2 ; \mathrm{c}=64.2 ; \mathrm{c}^{\prime}=0.6$; lateral field width $=11$; no. of tail annuli $=15$; phasmid 4 annuli anterior to anus level.

Body habitus upon relaxation double spiral. Body annuli $1.8 \pm 0.5(1.5-2.0)$ wide. Body without longitudinal striations in any region. Lip region with 6 annuli, hemispherical in profile $10.9 \pm 2.7(10.5-11.5)$ wide, $6.6 \pm 1.7$ (6.3-6.7) high. In few specimens, a seventh lip annulus could be counted, usually on only one of the two sides of the lip region. Centrally located on the circular oral disc is the oval opening of the prestoma which is surrounded by small pit-like openings of the six labial sensillae arranged three on each side. The oral disc is clearly separated from the first annulus of the lip region, which is divided into six sectors, with lateral sectors, bordering the amphidial apertures, smaller than the subventral and subdorsal sectors. Each amphidial opening appears as a 'half ellipse' between the oral disc and the lateral sectors of the first lip annulus. The lateral fields have four smooth 

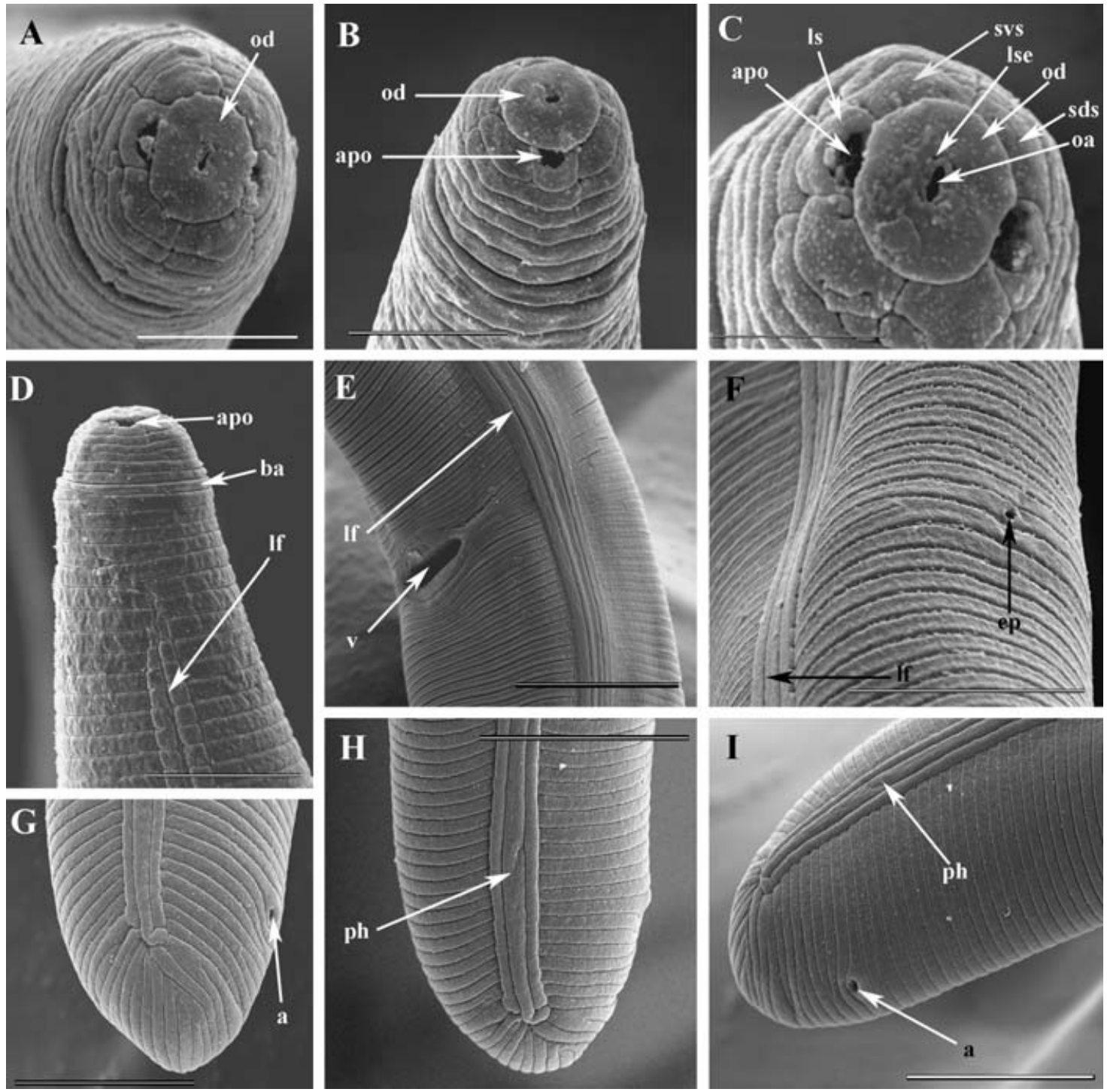

Fig. 3 A-I. Scanning electron microscope photographs of Rotylenchus montanus sp. n. - A-C. En face view showing oral aperture (oa), labial sensillae (lse), oral disc (od), lateral sectors (ls), subdorsal (sds) and subventral (svs) sectors. Pharyngeal and lip regions showing absence of longitudinal striations, and large oral disc (od) and amphidial opening (apo); - D. Anterior region showing smooth basal annulus (ba) and lateral field (lf); - E. Vulval (v) region showing lateral field at mid-body; —F. Excretory pore (ep) and lateral fields at level of pharyngeal region. -G-I. Tail region showing anus (a) and phasmid (ph). (Scale bars: A, C $=5 \mu \mathrm{m} ; \mathrm{B}, \mathrm{D}=10 \mu \mathrm{m} ; \mathrm{E}-\mathrm{I}=20 \mu \mathrm{m}$ ).

equidistant lines, beginning anteriorly at 12 th annulus as three lines forming two bands; after 6-12 annuli, central line divides to form a third band. The three bands are $9.4 \pm 2.4$ (8-11) wide at mid-body, approximately one-fifth as wide the body width. Regular areolation of the lateral fields (external bands) is observed in the pharyngeal region. Labial framework strongly developed. Stylet robust with rounded to anchor shaped basal knobs $6.5 \pm 1.7(6-7)$ wide. Orifice of dorsal pharyngeal gland about 5.0 from stylet base, $14.0 \pm 3.7$ (11.3-16.3)\% of stylet length. Procorpus cylindrical, narrowing slightly at junction with median pharyngeal bulb, $52.8 \pm 3.9$ $(45-55)$ long. Median pharyngeal bulb broadly oval $(12 \times 18)$, with well-developed valvular apparatus, 3.5-4.5 long. Nerve ring enveloping isthmus at middle, at 109.8 $\pm 5.1(99-115)$ from anterior end. The excretory pore is located at level, or slightly posterior to pharyngo-intestinal valve. It is visible by SEM as a small opening about half annulus within diameter. Pharyngeal glands sacciform, with three nuclei, overlapping intestine dorsally for about three-fourths of their length. Hemizonid 1.5-2 annuli long, just anterior to excretory pore. 
Table 2 Morphometrics of females of Rotylenchus montanus sp. n. Measurements are in $\mu \mathrm{m}$ and in the form: mean \pm SD and (range), unless otherwise stated.

\begin{tabular}{lcc}
\hline & \multicolumn{2}{l}{ Paratype females } \\
\cline { 2 - 3 } Character/ratios* $^{*}$ & Val di Non, Trento & Cervinia, Aosta \\
\hline $\mathrm{n}$ & 15 & 10 \\
$\mathrm{~L}$ & $1058 \pm 42.6(977-1135)$ & $1006 \pm 58.0(913-1089)$ \\
$\mathrm{a}$ & $26.7 \pm 0.7(24.8-27.8)$ & $25.4 \pm 0.9(23.8-27.0)$ \\
$\mathrm{b}$ & $7.4 \pm 0.3(6.8-7.8)$ & $7.3 \pm 0.4(6.7-7.8)$ \\
$\mathrm{b}^{\prime}$ & $6.3 \pm 0.3(5.8-6.7)$ & $6.1 \pm 0.5(5.5-6.8)$ \\
$\mathrm{C}$ & $57.0 \pm 7.2(47.4-69.5)$ & $53.6 \pm 6.9(43.6-64.3)$ \\
$\mathrm{C}^{\prime}$ & $0.7 \pm 0.1(0.6-0.8)$ & $0.7 \pm 0.1(0.6-0.8)$ \\
$\mathrm{V}$ & $55 \pm 1.6(52.5-58.0)$ & $55 \pm 1.4(52-56)$ \\
Stylet & $34.5 \pm 1.2(32.5-36.5)$ & $34.0 \pm 1.3(32.0-36.5)$ \\
Stylet conus & $16.0 \pm 1.0(14.5-17.5)$ & $16.0 \pm 1.1(14.5-17.5)$ \\
Knobs width & $6.5 \pm 0.4(6-7)$ & $6.5 \pm 0.4(5.5-6.5)$ \\
DGO & $5.0 \pm 0.4(4-5.5)$ & $6.0 \pm 0.9(4.5-7.5)$ \\
Head to centre of median bulb & $100 \pm 4.2(93-107)$ & $92.5 \pm 3.3(89-99)$ \\
Pharynx (to valve) & $144 \pm 5.6(137-153)$ & $138 \pm 4.0(133-145)$ \\
Head to pharyngeal gland tip & $168 \pm 8.0(158-183)$ & $166 \pm 7.0(157-182)$ \\
Pharyngeal overlap & $24 \pm 3.5(18-31)$ & $27.5 \pm 6.0(19.5-36.5)$ \\
Anterior end to excretory pore & $151 \pm 5.7(142-167)$ & $135 \pm 5.0(127-143)$ \\
Maximum body width & $39.5 \pm 1.5(37.5-42)$ & $39.5 \pm 2.5(35.5-42.5)$ \\
Anal body width & $27.0 \pm 1.3(25.5-30)$ & $27.5 \pm 2.0(24.5-30.5)$ \\
Tail length & $19.0 \pm 2.3(15.5-23.5)$ & $19.0 \pm 3.1(15.5-24.0)$ \\
No. of tail annuli & $15 \pm 1.6(12-18)$ & $17 \pm 2.4(14-22)$ \\
Phasmid to terminus & $28.0 \pm 2.9(23.5-35.5)$ & $26.5 \pm 3.2(20.5-30.5)$ \\
\hline
\end{tabular}

*Abbreviations are defined in Siddiqi (2000).

Reproductive system with two equally developed genital branches; anterior branch $213 \pm 27$ (147-254) long, posterior branch $208 \pm 28$ (155-246) long, respectively, $20 \pm 2.4(15-25)$ and $20 \pm 2.7$ (14-24)\% of body length. Ovaries with a single row of 12-15 oocytes. Vulva slightly posterior to mid-body, with non-protruding epiptygma. Spermatheca spherical 18-22 wide, but nonfunctional and without sperm; uterus quadricolumellar. Phasmids pore-like, anterior to anus, 12 14 annuli distant from lateral field terminus. Tail rounded, often with a slight depression on dorsal margin; tail terminus regularly annulated.

Male. Not found.

\section{Results of morphometrical and SEM studies of some Rotylenchus species (Figs 4 and 5, Table 4)}

Morphometrical studies (Table 4) as well as SEM observations (Figs 4 and 5) of the five Spanish populations of the genus Rotylenchus ( $R$. eximius, $R$. goodeyi, $R$. laurentinus, $R$. incultus Sher 1965 and R. unisexus Sher 1965) showed typical traits for each of the five species as described in the literature (Castillo \& Vovlas 2005), except for some minor differences in some measurements and ratios, which confirms intraspecific variability previously reported (Castillo \& Vovlas 2005). The new report of $R$. laurentinus from southern Spain represents the first record of this species in the country, and also is the first time this species is reported outside of Italy, where it was only previously reported (Castillo \& Vovlas 2005). The remaining four species had been previously recorded in several localities in Spain but no SEM studies had ever been developed on them (Castillo \& Vovlas 2005).

SEM observations of $R$. goodeyi showed the characteristic basal annulus of the lip region subdivided by longitudinal striations (12-18) (Fig. 4A). En face views showed an oval oral aperture centrally located in a rounded labial disc which is

Table 3 Comparison of Rotylenchus montanus sp. n. with closer Rotylenchus species.

\begin{tabular}{|c|c|c|c|c|c|c|c|c|c|c|c|}
\hline \multirow[b]{2}{*}{ Rotylenchus spp. } & \multicolumn{11}{|c|}{ Morphological characters* } \\
\hline & $\begin{array}{l}\mathrm{A}_{1-7} \\
\text { Lip } \\
\text { annulation }\end{array}$ & $\begin{array}{l}\mathrm{B}_{1-4} \\
\text { Lip } \\
\text { region shape }\end{array}$ & $\begin{array}{l}\mathrm{C}_{1-7} \\
\text { Lateral field } \\
\text { areolation }\end{array}$ & $\begin{array}{l}\mathrm{D}_{1-4} \\
\text { Body longitudinal } \\
\text { striations }\end{array}$ & $\begin{array}{l}\mathrm{E}_{1-4} \\
\text { Stylet } \\
\text { length }\end{array}$ & $\begin{array}{l}\mathrm{F}_{1-4} \\
(\mathrm{DGO} \text { in } \mu \mathrm{m})\end{array}$ & $\begin{array}{l}\mathrm{G}_{1-5} \\
\text { Pharyngeal } \\
\text { overlapping in } \mu \mathrm{m}\end{array}$ & $\begin{array}{l}\mathrm{H}_{1-5} \\
\text { Tail } \\
\text { shape }\end{array}$ & $\begin{array}{l}\mathrm{I}_{1-3} \\
\text { Vulva } \\
\text { position (V\%) }\end{array}$ & $\begin{array}{l}J_{1-2} \\
\text { Presence } \\
\text { of males }\end{array}$ & $\begin{array}{l}\mathrm{K}_{1-3} \\
\text { Phasmid } \\
\text { position }\end{array}$ \\
\hline arsenjevi & A5 & B3 & $\mathrm{C} 1$ & D4 & E2 & $\mathrm{F} 2$ & $\mathrm{G} 2$ & $\mathrm{H} 2$ & 12 & $\mathrm{~J} 2$ & K3 \\
\hline corsicus & A4 & B1 & $\mathrm{C} 1$ & $\mathrm{D} 2$ & E2 & $\mathrm{F} 2$ & $\mathrm{G} 2$ & $\mathrm{H} 3$ & 12 & $\mathrm{~J} 2$ & $\mathrm{~K} 1$ \\
\hline fragaricus & A4 & B4 & $\mathrm{C} 1$ & D4 & E2 & $\mathrm{F} 2$ & G3 & $\mathrm{H} 2$ & 12 & $J 2$ & $\mathrm{~K} 2$ \\
\hline helicus & A4 & B1 & $\mathrm{C} 1$ & D4 & E2 & $\mathrm{F} 4$ & G4 & $\mathrm{H} 2$ & 12 & $\mathrm{~J} 2$ & $\mathrm{~K} 2$ \\
\hline indorobustus & A6 & B2 & $\mathrm{C} 1$ & D4 & E2 & $\mathrm{F} 2$ & G3 & $\mathrm{H} 1$ & 12 & $\mathrm{~J} 2$ & $\mathrm{~K} 2$ \\
\hline montanus sp. $\mathrm{n}$. & A5 & B1 & $\mathrm{C} 1$ & D4 & E2 & $\mathrm{F} 2$ & G3 & $\mathrm{H} 2$ & 12 & $\mathrm{~J} 2$ & $\mathrm{~K} 2$ \\
\hline neorobustus & A5 & B1 & $\mathrm{C} 1$ & D4 & E3 & $\mathrm{F} 4$ & G3 & $\mathrm{H} 3$ & 12 & $J 2$ & K1 \\
\hline
\end{tabular}

* Morphological characters according to Castillo \& Vovlas (2005). Group A: 1, lip region (I.r.) annulation absent or smooth; 2, I.r. with 2-3 annuli; 3, I.r. with 4 annuli; 4, I.r. with 5 annuli; 5, I.r. with 6 annuli; 6, I.r. with 7-8 annuli; 7, I.r. with 9-10 annuli. Group B: 1, I.r. hemispherical; 2, I.r. rounded; 3, I.r. conoid; 4, I.r. truncate. Group C: 1, only in pharyngeal region (ph. reg.); 2 in ph. reg. and irregularly at mid-body; 3 , in ph. reg. and incompletely at mid-body; 4 , in ph. reg. and near phasmids; 5 , whole body length except tail region; 6, whole body length included tail region; 7 , incompletely along whole body. Group D: 1, punctuated along body annuli; 2 , longitudinally striated in ph. reg.; 3, longitudinally striated over whole body; 4, without body striations. Group E: 1, <30 $\mu \mathrm{m} ; 2$, by 30-35.9 $\mu \mathrm{m} ; 3$, by 36-40.9 $\mu \mathrm{m} ; 4,>41 \mu \mathrm{m}$. Group F: 1, <2 2 m; 2, by $2-6.9 \mu \mathrm{m} ; 3$, by 7-12 $\mu \mathrm{m}$; 4, > $12 \mu \mathrm{m}$. Group G: 1, <5 $\mu \mathrm{m} ; 2$, by 6-20.9 $\mu \mathrm{m} ; 3$, by 21-30.9 $\mu \mathrm{m} ; 4$, by 31-40.9 $\mu \mathrm{m} ; \mathbf{5},>41 \mu \mathrm{m}$. Group H: 1, hemispherical; 2, rounded; 3, conoid; 4, pointed; 5, with ventral projection. Group I: 1, <50\%; 2, by 50-70\%; 3, $>70 \%$. Group J: 1, present; 2, absent. Group K: 1, $>5$ annuli anterior to anus; 2 , from 5 anterior to 5 posterior to anus; $3,>5$ annuli posterior to anus. 

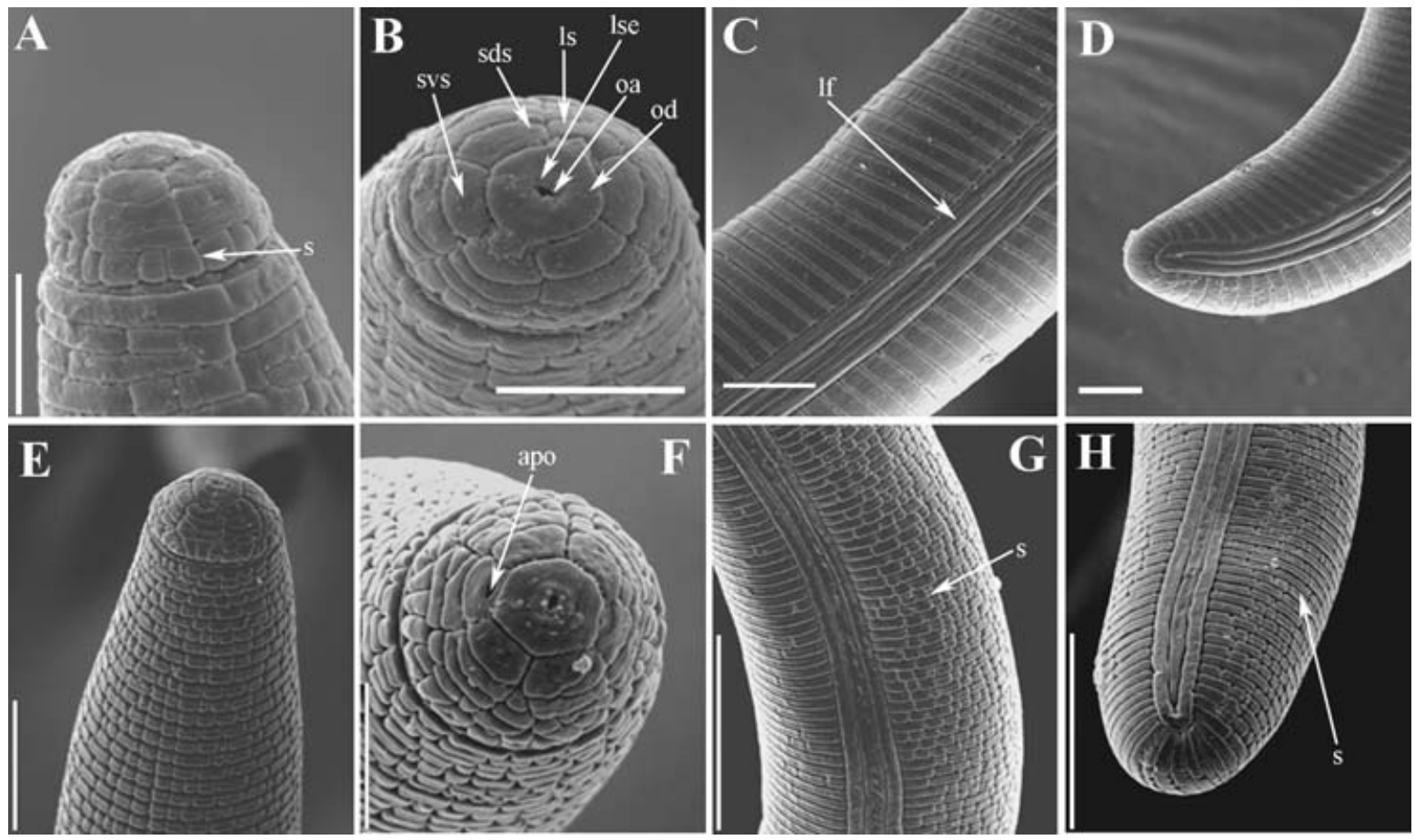

Fig. 4 A-H. Scanning electron microscope photographs of Rotylenchus goodeyi Loof \& Oostenbrink 1958 (A-D) and Rotylenchus laurentinus Scognamiglio \& Talamé 1973 (E-H). —A. Lip region showing longitudinal striations (s) on basal annulus; —B. En face view showing oral aperture (oa), labial sensillae (lse), oral disc (od), lateral sectors (ls), subdorsal (sds) and subventral (svs) sectors; -C. Lateral field (lf) at midbody; -D. Tail region; - E. Pharyngeal region showing longitudinal striation; - F. En face view showing oral disc, sectors and amphidial opening (apo); - G. Longitudinal striations at mid-body. $-\mathrm{H}$. Tail region showing longitudinal striation. (Scale bars: $\mathrm{A}-\mathrm{E}=10 \mu \mathrm{m} ; \mathrm{F}=5 \mu \mathrm{m}$; $\mathrm{G}, \mathrm{H}=20 \mu \mathrm{m})$.

surrounded by small pit-like openings of the six labial sensilla arranged three on each side of the oral aperture (Fig. 4A,B). Oral disc is clearly separated from the first lip annulus which has the lateral sectors smaller than the subdorsal and subventral sectors (Fig. 4A,B). Cuticle irregularly areolated at the pharyngeal region, but smooth in the rest of body, including lateral fields (Fig. 4C,D). SEM observations of R. laurentinus showed the typical and characteristics longitudinal striations over whole body (Fig. 4E-H), and hexagonal labial disc (Fig. 4E,F) as previously reported from a population from the Adriatic coast (Vovlas et al. 1980). En face view of $R$. eximius showed a rounded oral aperture centrally located in a rounded labial disc clearly separated from the first lip annulus and fused with lateral sectors (Fig. 5A). Cuticle without striation along whole body, including pharyngeal region (Fig. 5B-D). SEM observations of $R$. incultus showed a hemispherical lip region with the basal annulus subdivided by irregular longitudinal striations (14-16) (Fig. 5E). En face views showed a rounded oral disc clearly separated from the lateral sectors which were about half size of the subdorsal and subventral sectors (Fig. 5F). Cuticle irregularly areolated at the pharyngeal region, but smooth in the rest of body, including lateral fields (Fig. 5E-H).

\section{Results of the molecular study}

Molecular characterization of Rotylenchus montanus sp. $n$. Sequence and phylogenetic analyses of D2-D3 alignment of $R$. montanus sp. $\mathrm{n}$. were carried out using specimens of the population collected from apple orchards in Val di Non, Trento province. These analyses revealed that sequence of $R$. montanus $\mathrm{sp}$. $\mathrm{n}$. is very similar to that of an unidentified Rotylenchus species from Russia and differed from it by one nucleotide only. The D2-D3 of R. montanus sp. n. differed from those of $R$. agnetis in 43 nucleotides (7.7\%). TW81 and 5.8SM5 primers amplified an amplicon of approximately $825 \mathrm{bp}$ in length for $R$. montanus sp. $\mathrm{n}$ and an unidentified Rotylenchus species from Russia. Differences in the amplified fragment of 18S-ITS1-5.8S of rRNA sequences between these two species were in 16-20 nucleotides (1.9-2.4\%) and two indels, whereas as differences between two clones of the ITS sequences for R. montanus sp. $\mathrm{n}$. was six nucleotides (0.7\%). The ITS-rRNA of R. montanus sp. n. 

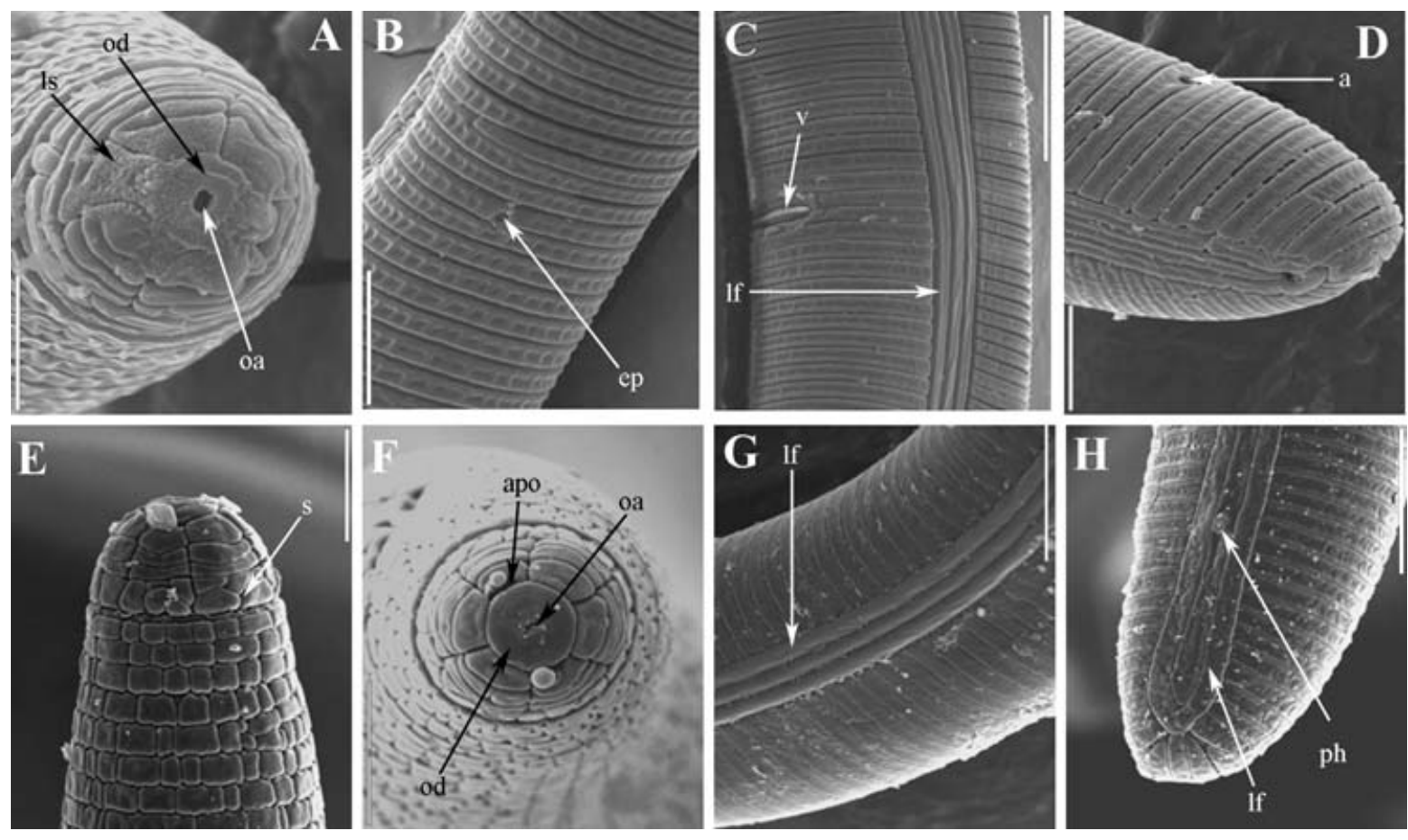

Fig. 5 A-H. Scanning electron microscope photographs of Rotylenchus eximius Siddiqi 1964 (A-D) and Rotylenchus incultus Sher 1965 (E-H). -A. En face view showing oral aperture (oa), oral disc (od), lateral sectors (ls); - B. Detail of excretory pore (ep) region showing absence of longitudinal striations; —C. Vulval (v) region showing lateral field (lf) at mid-body; —D. Tail region showing anus; - E. Lip region sowing longitudinal striations (s) in the basal annulus and pharyngeal region; - F. En face view showing oral aperture (oa), oral disc (od), sectors and amphidial opening (apo); G, Lateral fields (lf) at mid-body; H, Tail region showing phasmid (ph) and lateral fields (lf). (Scale bars: A, B, E, $\mathrm{F}=5 \mu \mathrm{m} ; \mathrm{C}, \mathrm{G}=20 \mu \mathrm{m} ; \mathrm{D}, \mathrm{H}=10 \mu \mathrm{m})$.

differed from those of $R$. brevicaudatus in 141-142 nucleotides $(23 \%)$.

\section{Molecular characterization of other Rotylenchus species}

Molecular analysis of D2-D3 sequences revealed several Rotylenchus groups with similar sequences. Sequence of $R$. goodeyi was identical to that of $R$. incultus and different from the sequences of two $R$. laurentinus populations in one-two nucleotides (0.17-0.35\%). Rotylenchus uniformis/R. robustus: intraspecific variation for $R$. uniformis was $0-4$ nucleotides $(0-0.7 \%)$. Differences between $R$. robustus and $R$. uniformis varied from 0 to 2 nucleotides $(0-0.35 \%)$. Sequences for two populations of $R$. magnus were identical and differed from that of $R$. jaeni in 10 nucleotides (1.7\%).

Variation in the length of amplicon and interspecific sequence variation for Rotylenchus were significantly higher in the ITS region than in the D2-D3 expansion segments of rRNA. Length of the ITS-PCR products varied from approximately 740 (R. jaeni) to 870 bp (R. unisexus). Analysis of sequences revealed nucleotide and length variations between the ITS clones within same nematode samples.
Highest nucleotide variation (4.1\%) was observed between two the ITS clone sequence of $R$. incultus.

TW81 and 5.8SM5 primers amplified a PCR product of the ITS-rRNA fragment in approximately $760 \mathrm{bp}$ in length for $R$. magnus and $740 \mathrm{bp}$ for $R$. jaeni. Sequence variation within four ITS clones of two $R$. magnus populations was 1-17 nucleotides (0.1-2.3\%), and within two ITS clones of R. jaeni was 1 nucleotide $(0.1 \%)$ only, whereas interspecific variation between these species was 19-26 nucleotides (2.7$3.5 \%)$.

The size of ITS amplicons for $R$. incultus and $R$. laurentinus was approximately $860 \mathrm{bp}$. Sequences of two ITS clones differed in 6 nucleotides $(0.7 \%)$ for $R$. laurentinus and in 34 nucleotides $(3.9 \%)$ for $R$. incultus. Differences between these two species varied from 32 to 35 nucleotides (3.7$4.1 \%)$.

TW81 and 5.8SM5 primers amplified a PCR product of the ITS-rRNA fragment in approximately 805 bp in length for $R$. cazorlaensis. Sequence differences between four ITS clones of two samples varied from 5 to 17 nucleotides (0.5-2.1\%). 
N. Vovlas et al. • R. montanus sp. n. and molecular phylogeny of the genus Rotylenchus

Table 4 Morphometrics of females and males of Rotylenchus species from southern Spain. Measurements are in $\mu \mathrm{m}$ and in the form: $\mathrm{mean} \pm \mathrm{SD}$ (range)*.

\begin{tabular}{|c|c|c|c|c|c|c|}
\hline \multirow[b]{2}{*}{ Character-ratio } & \multirow{2}{*}{$\begin{array}{l}\text { R. goodeyi } \\
\text { (Vejer de la Frontera) } \\
\text { (Cádiz province) } \\
\text { Females }\end{array}$} & \multicolumn{2}{|c|}{$\begin{array}{l}\text { R. laurentinus } \\
\text { Zahara de los Atunes } \\
\text { (Cádiz province) }\end{array}$} & \multicolumn{2}{|c|}{$\begin{array}{l}\text { R. incultus } \\
\text { Bollullos and Niebla } \\
\text { (Huelva province) }\end{array}$} & \multirow{2}{*}{$\begin{array}{l}\text { R. unisexus } \\
\text { Alcalá de Guadaira } \\
\text { (Seville province) } \\
\text { Females }\end{array}$} \\
\hline & & Females & Males & Females & Males & \\
\hline $\mathrm{n}$ & 20 & 20 & 18 & 20 & 18 & 14 \\
\hline L & $\begin{array}{l}998 \pm 0.2 \\
(830-1140)\end{array}$ & $\begin{array}{l}1018 \pm 66.4 \\
(931-1118)\end{array}$ & $\begin{array}{l}931 \pm 36.9 \\
(884-966)\end{array}$ & $\begin{array}{l}880 \pm 67.6 \\
(787-991)\end{array}$ & $\begin{array}{l}768 \pm 82.4 \\
(633-856)\end{array}$ & $\begin{array}{l}721 \pm 26.9 \\
(694-748)\end{array}$ \\
\hline a & $\begin{array}{l}29.5 \pm 0.8 \\
(21.2-35.6)\end{array}$ & $\begin{array}{l}30.5 \pm 1.8 \\
(28.2-31.9)\end{array}$ & $\begin{array}{l}32.4 \pm 0.5 \\
(31.7-32.9)\end{array}$ & $\begin{array}{l}31.5 \pm 2.6 \\
(28.3-36.7)\end{array}$ & $\begin{array}{l}31.3 \pm 2.6 \\
(27.5-34.2)\end{array}$ & $\begin{array}{l}26.3 \pm 0.7 \\
(25.6-27.1)\end{array}$ \\
\hline b & $\begin{array}{l}6.6 \pm 0.2 \\
(5.7-9.2)\end{array}$ & $\begin{array}{l}6.9 \pm 0.4 \\
(6.6-7.5)\end{array}$ & $\begin{array}{l}6.3 \pm 0.3 \\
(5.9-6.7)\end{array}$ & $\begin{array}{l}6.7 \pm 0.8 \\
(5.4-7.7)\end{array}$ & $\begin{array}{l}6.3 \pm 0.8 \\
(5.4-7.7)\end{array}$ & $\begin{array}{l}6.1 \pm 0.3 \\
(5.8-6.5)\end{array}$ \\
\hline c & $\begin{array}{l}50.9 \pm 9.1 \\
(37.0-75.4)\end{array}$ & $\begin{array}{l}43.7 \pm 3.2 \\
(40.5-48.2)\end{array}$ & $\begin{array}{l}36.2 \pm 2.3 \\
(34.0-38.3)\end{array}$ & $\begin{array}{l}43.1 \pm 4.9 \\
(35.5-49.6)\end{array}$ & $\begin{array}{l}31.0 \pm 2.3 \\
(28.1-33.7)\end{array}$ & $\begin{array}{l}39.3 \pm 8.3 \\
(31.0-47.6)\end{array}$ \\
\hline$c^{\prime}$ & $\begin{array}{l}0.95 \pm 0.1 \\
(0.60-1.28)\end{array}$ & $\begin{array}{l}0.90 \pm 0.1 \\
(0.84-1.00)\end{array}$ & $\begin{array}{l}1.5 \pm 0.2 \\
(1.3-1.7)\end{array}$ & $\begin{array}{l}0.97 \pm 0.1 \\
(0.87-1.11)\end{array}$ & $\begin{array}{l}1.4 \pm 0.14 \\
(1.19-1.56)\end{array}$ & $\begin{array}{l}0.95 \pm 0.2 \\
(0.8-1.1)\end{array}$ \\
\hline V or T & $\begin{array}{l}53.7 \pm 0.4 \\
(49-57)\end{array}$ & $\begin{array}{l}55.8 \pm 1.3 \\
(54-57)\end{array}$ & $\begin{array}{l}45.8 \pm 4.3 \\
(41-51)\end{array}$ & $\begin{array}{l}54.7 \pm 2.2 \\
(51-58)\end{array}$ & $\begin{array}{l}44.8 \pm 9.1 \\
(36-61)\end{array}$ & $\begin{array}{l}55.8 \pm 2.3 \\
(53-57)\end{array}$ \\
\hline Stylet & $\begin{array}{l}30.5 \pm 0.3 \\
(28-32)\end{array}$ & $\begin{array}{l}31.6 \pm 0.7 \\
(31.0-32.5)\end{array}$ & $\begin{array}{l}30.3 \pm 1.0 \\
(29-31)\end{array}$ & $\begin{array}{l}26.6 \pm 1.1 \\
(25.0-28.0)\end{array}$ & $\begin{array}{l}24.0 \pm 1.4 \\
(23-26)\end{array}$ & $\begin{array}{l}27.3 \pm 1.0 \\
(26-28)\end{array}$ \\
\hline 0 & $\begin{array}{l}12.1 \pm 0.9 \\
(7.1-18.2)\end{array}$ & $\begin{array}{l}16.8 \pm 1.4 \\
(15.8-18.5)\end{array}$ & $\begin{array}{l}14.8 \pm 1.8 \\
(12.9-16.7)\end{array}$ & $\begin{array}{l}13.5 \pm 1.5 \\
(11.1-15.4)\end{array}$ & $\begin{array}{l}13.9 \pm 1.7 \\
(12.0-15.4)\end{array}$ & $\begin{array}{l}15.8 \pm 1.6 \\
(13.9-17.7)\end{array}$ \\
\hline Spicule length & - & - & $\begin{array}{l}30.5 \pm 1.3 \\
(29-32)\end{array}$ & - & $\begin{array}{l}26.2 \pm 1.0 \\
(25-28)\end{array}$ & - \\
\hline Gubernaculum & - & - & $\begin{array}{l}14.8 \pm 0.9 \\
(14-16)\end{array}$ & - & $\begin{array}{l}12.3 \pm 1.2 \\
(11-14)\end{array}$ & - \\
\hline Phasmid locationt & $\begin{array}{l}\text { (+) } 5.6 \pm 0.6 \\
(1-11)\end{array}$ & $\begin{array}{l}(+) 4.1 \pm 0.3 \\
(3-6)\end{array}$ & - & $\begin{array}{l}(+) 3.1 \pm 0.4 \\
(2-4)\end{array}$ & - & $\begin{array}{l}(+) 6.1 \pm 0.8 \\
(5-8)\end{array}$ \\
\hline
\end{tabular}

*Abbreviations are defined in Siddiqi (2000).

tNumber of body annuli anterior (+) or posterior (-) to anus level.

Phylogenetic position of Rotylenchus montanus sp. n. within the genus and phylogenetic relationships within Hoplolaimidae The D2-D3 alignment includes 45 sequences with 608 positions in length. Majority consensus phylogenetic tree generated from the D2-D3 data set by BI analysis under the complex model is presented in Fig. 6. The three topologies obtained by MP and BI analyses were congruent. Rotylenchus montanus $\mathrm{sp}$. $\mathrm{n}$. formed a highly supported clade with an unidentified Rotylenchus species from Russia. Rotylenchus species represents seven moderately or highly supported lineages: (i) $R$. incultus, $R$. goodeyi, R. laurentinus; (ii) R. montanus sp. n., Rotylenchus sp. and $R$. agnetis; (iii) $R$. unisexus; (iv) $R$. robustus and $R$. uniformis; (v) R. magnus and R. jaeni; (vi) R. cazorlaensis; and (vii) R. eximius. Helicotylenchus species formed two clades: highly supported clade included Helicotylenchus pseudorobustus (Steiner 1914) Golden 1945, Helicotylenchus sp. 1 and H. multicinctus (Cobb 1893) Golden 1956 and moderately supported clade with $H$. vulgaris Yuen 1964, H. digonicus Perry 1959 and three unidentified Helicotylenchus species. Relationships between these main groups of Rotylenchus as well as between main clades of Hoplolaimidae, including representatives of the subfamily Hoplolaiminae Filipjev 1934 (Scutellonema, Hoplolaimus and Peltamigratus) are not well resolved.
The ClustalX generated the alignment for 22 ITS sequences of Rotylenchus samples in 875 positions in the length. After discarding ambiguously aligned regions from the alignment, the ITS-5.8S data set includes 460 positions. Majority consensus phylogenetic tree generated from this data set by BI analysis under the GTR + G + I model is presented in Fig. 7. Consensus MP tree had a similar topology. Rotylenchus montanus sp. n. formed a highly supported clade with Rotylenchus sp. from Russia. The branch with $R$. montanus sp. n. was supported by one autapomorphy (unique nucleotide). Sister relationships have been revealed for $R$. magnus and $R$. jaeni, $R$. laurentinus and $R$. incultus and these clades are supported by 25 and 67 synapomorphies, respectively. The branch with $R$. jaeni comb. n. was supported by three autapomorphies.

\section{Discussion}

Morphological comparison of Rotylenchus montanus sp. $n$. with related taxa

Rotylenchus montanus sp. n. from both type localities were identical morphologically, but some minor morphometrical differences between them were detected, that is, population 


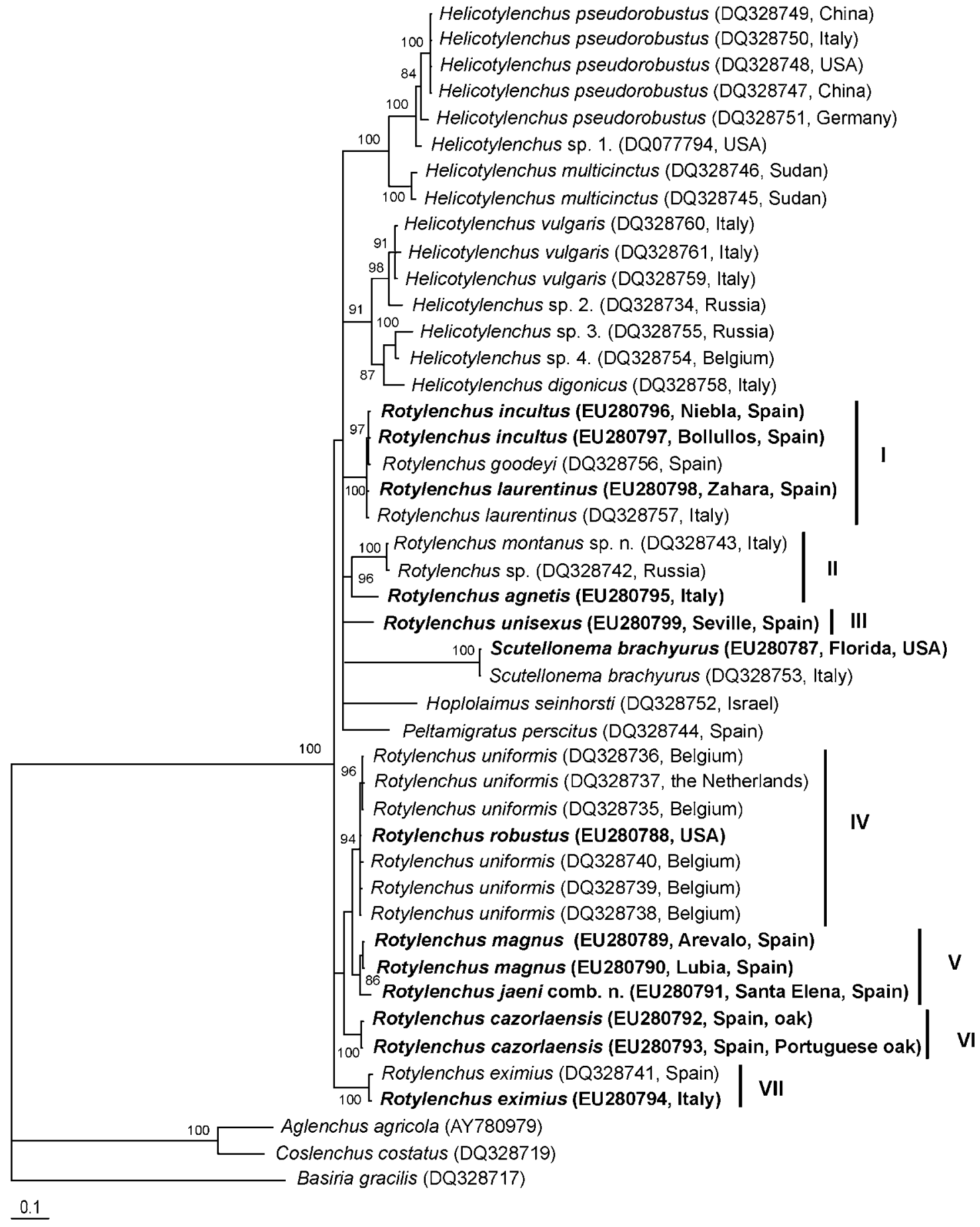

Fig. 6 The 50\% majority rule consensus trees from Bayesian analysis generated from the D2-D3 of 28S rRNA gene data set with the complex model: $4 \times 4$ model for loops and 16 doublets model for stems. PP values more than $70 \%$ are given in appropriate clades. Newly sequenced samples are indicated by bold font. 
Fig. 7 The $50 \%$ majority rule consensus trees from Bayesian analysis generated from the reduced ITS-rRNA gene data set with the GTR + G + I model. Tree is rooted with $R$. eximius. PP values more than $70 \%$ are given in appropriate clades. Newly sequenced samples are indicated by bold font.

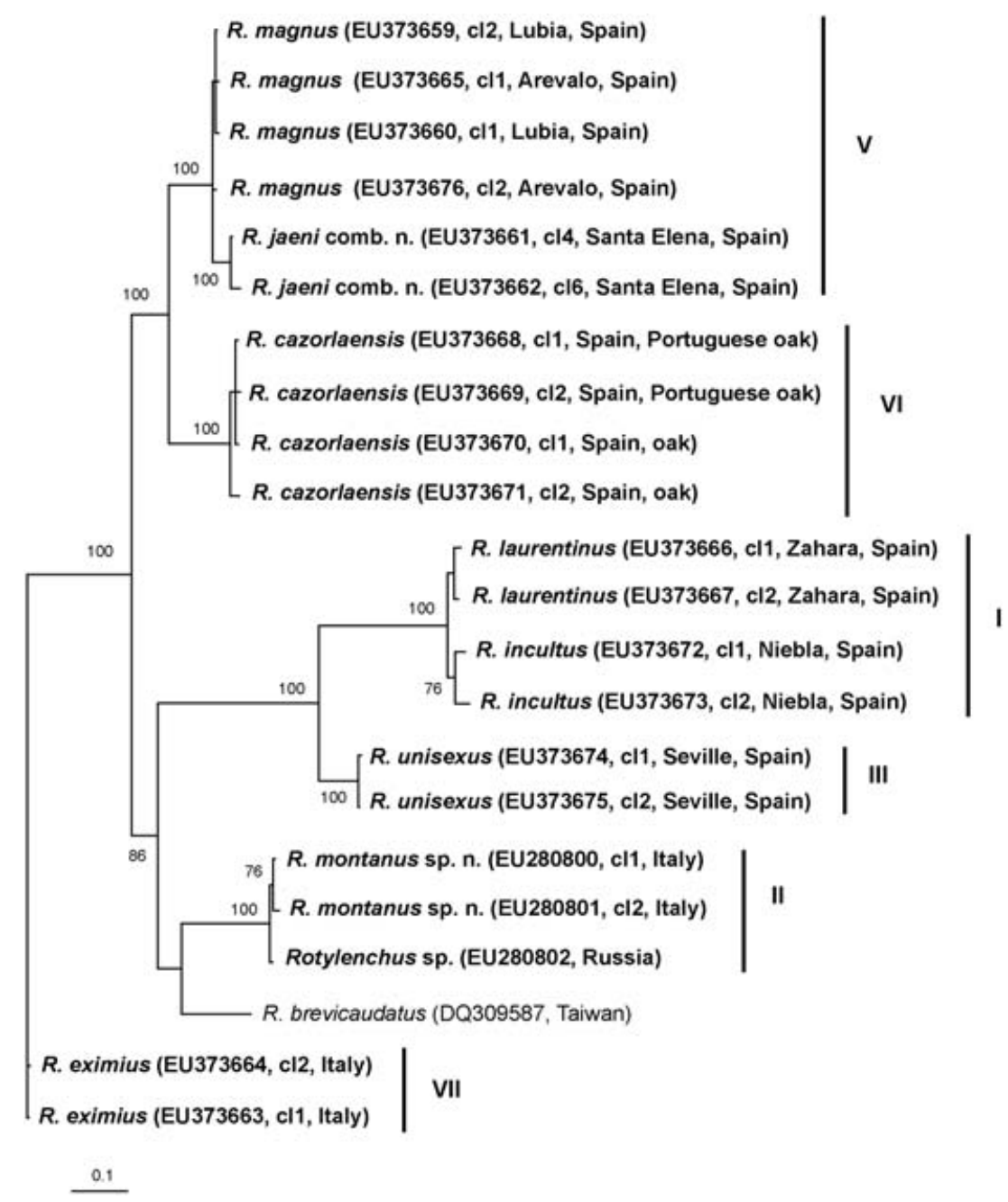

from Trento showed slightly larger lip region, excretory pore distance and pharyngeal overlap than that of Cervinia population while DGO was slightly longer in Cervinia population. Rotylenchus montanus sp. n. can be distinguished from closer species of the group ( $R$. arsenjevi (Eroshenko 1984) Maggenti et al. 1988, R. corsicus Scotto La Massèse \& Germani 2000, $R$. fragaricus Maqbool \& Shahina 1986, R. helicus Husain \& Khan 1967, R. indorobustus Jairajpuri \& Baqri 1973, and $R$. neorobustus Sultan \& Jairajpuri 1979) by a number of specific characteristics (Table 3) resulting from its specific matrix code (A5, B1, C1, D4, E2, F2, G3, H2, I2, J2, K2). Rotylenchus montanus sp. $\mathrm{n}$. is close to $R$. neorobustus in general morphology but can be distinguished by shorter stylet length (33-37 vs. 36-40), basal annulus of lip region (smooth vs. marked with 24 longitudinal striations), DGO from base of stylet (4-5.5 vs. 6-13), tail shape (rounded vs. conoid), and phasmid position. From $R$. arsenjevi it differs by longer body (977-1135 vs. 700900), longer stylet (33-37 vs. 29-32), shorter DGO from base of stylet (4-5.5 vs. 7-8) and tail with $12-18$ annuli vs. 7-9 annuli. From $R$. corsicus it differs by the number of lip annuli (6-7 vs. 4-5), stylet basal knobs mostly rounded vs. anteriorly indented, slightly longer pharyngeal gland overlapping (24 vs. 17), tail shape (rounded vs. conoid) and phasmid position. From $R$. fragaricus it differs by the number of lip annuli (6-7 vs. 4-5), lip region shape (hemispherical vs. truncate) and shorter pharyngeal gland overlapping (24 vs. 25-30). From $R$. helicus it differs by the number of lip annuli (6-7 vs. 5), shorter DGO (4-5.5 vs. 15-18) and lateral fields with smooth incisures vs. crenate. From $R$. indorobustus it differs by the slightly longer stylet (33-37 vs. 32-35), stylet basal knobs nearly rounded vs. anteriorly pointed, number of lip region annuli (6-7 vs. 7-8), basal annulus of lip region smooth vs. marked with 24 longitudinal striations and shorter DGO (4-5.5 vs. 6-7). In addition, $R$. montanus sp. n. can be also differentiated from $R$. agnetis by lip region shape (hemispherical vs. rounded), shorter DGO (4-5.5 vs. 5.5-7.5), tail shape 
R. montanus sp. n. and molecular phylogeny of the genus Rotylenchus $\bullet$ N. Vovlas et al.

Table 5 Comparison of Rotylenchus species with similar D2-D3 sequences.

\begin{tabular}{|c|c|c|c|c|c|c|c|c|c|c|c|}
\hline \multirow[b]{2}{*}{ Rotylenchus spp. } & \multicolumn{11}{|c|}{ Morphological characters* } \\
\hline & $\begin{array}{l}A_{1-7} \\
\text { Lip } \\
\text { annulation }\end{array}$ & $\begin{array}{l}\mathrm{B}_{1-4} \\
\text { Lip } \\
\text { region shape }\end{array}$ & $\begin{array}{l}\mathrm{C}_{1-7} \\
\text { Lateral } \\
\text { field areolation }\end{array}$ & $\begin{array}{l}\mathrm{D}_{1-4} \\
\text { Body longitudinal } \\
\text { striations }\end{array}$ & $\begin{array}{l}E_{1-4} \\
\text { Stylet } \\
\text { length }\end{array}$ & $\begin{array}{l}F_{1-4} \\
D G O \text { in } \mu \mathrm{m}\end{array}$ & $\begin{array}{l}\mathrm{G}_{1-5} \\
\text { Pharyngeal } \\
\text { overlapping in } \mu \mathrm{m}\end{array}$ & $\begin{array}{l}\mathrm{H}_{1-5} \\
\text { Tail } \\
\text { shape }\end{array}$ & $\begin{array}{l}\mathrm{I}_{1-3} \\
\text { Vulva } \\
\text { position (V\%) }\end{array}$ & $\begin{array}{l}J_{1-2} \\
\text { Presence } \\
\text { of males }\end{array}$ & $\begin{array}{l}\mathrm{K}_{1-3} \\
\text { Phasmid } \\
\text { position }\end{array}$ \\
\hline goodeyi & A3 & B1 & $\mathrm{C} 1$ & D4 & E2 & F2 & G4 & $\mathrm{H} 2$ & 12 & $\mathrm{~J} 1$ & K2 \\
\hline incultus & A4 & B1 & $\mathrm{C} 1$ & D4 & E1 & F2 & G3 & H1 & 12 & J1 & K1 \\
\hline laurentinus & A4 & B1 & $\mathrm{C} 1$ & D3 & E2 & F2 & G3 & $\mathrm{H} 1$ & 12 & $\mathrm{~J} 1$ & K2 \\
\hline
\end{tabular}

*Morphological characters according to Castillo \& Vovlas (2005). Group A: 1, lip region (I.r.) annulation absent or smooth; 2, I.r. with 2-3 annuli; 3, I.r. with 4 annuli; 4, I.r. with 5 annuli; 5, I.r. with 6 annuli; 6, I.r. with 7-8 annuli; 7, I.r. with 9-10 annuli. Group B: 1, I.r. hemispherical; 2, I.r. rounded; 3, I.r. conoid; 4, I.r. truncate. Group C: 1, only in pharyngeal region (ph. reg.); 2 , in ph. reg. and irregularly at mid-body; 3 , in ph. reg. and incompletely at mid-body; 4 , in ph. reg. and near phasmids; 5 , whole body length except tail region; 6, whole body length included tail region; 7 , incompletely along whole body. Group D: 1 , punctuated along body annuli; 2 , longitudinally striated in ph. reg.; 3 , longitudinally striated over whole body; 4, without body striations. Group E: $1,<30 \mu \mathrm{m} ; 2$, by 30-35.9 $\mu \mathrm{m} ; 3$, by 36-40.9 $\mu \mathrm{m} ; 4$, $>41 \mu \mathrm{m}$. Group F: 1, $<2 \mu \mathrm{m} ; 2$, by $2-6.9 \mu \mathrm{m} ; 3$, by 7-12 $\mu \mathrm{m}$; 4, $>12 \mu \mathrm{m}$. Group G: $1,<5 \mu \mathrm{m} ; 2$, by 6-20.9 $\mu \mathrm{m} ; 3$, by 21-30.9 $\mu \mathrm{m} ; 4$, by 31-40.9 $\mu \mathrm{m} ; 5$, $>41 \mu \mathrm{m}$. Group H: 1, hemispherical; 2 , rounded; 3, conoid; 4, pointed; 5, with ventral projection. Group I: 1, $<50 \% ; 2$, by 50-70\%; 3, $>70 \%$. Group J: 1, present; 2, absent. Group K: 1, $>5$ annuli anterior to anus; 2 , from 5 anterior to 5 posterior to anus; $3,>5$ annuli posterior to anus. Dappled values indicate differences among the three species.

(rounded vs. conoid) and absence vs. presence of males. Similarly, R. montanus sp. n. can be also differentiated from R. brevicaudatus by the number of lip region annuli (6-7 vs. 4), lip region shape (hemispherical vs. rounded), longer stylet length (33-37 vs. 22-28), tail shape (rounded vs. hemispherical), absence vs. presence of males and phasmid position. Presence of unique molecular characters (autapomorphy) also justify distinguishing this nematode as a new species.

In the dichotomous key by Castillo \& Vovlas (2005) the new species should be included in step ' 13 ', 'lip region with more than four annuli', but we have noted a mistake that instead of choice 35 should lead to choice 36 , and then choice 66 'lip region with more than five annuli', a group which includes 29 species, the new step after 69 should differentiate between $R$. neorobustus and $R$. montanus sp. n. using the previous referred characteristics (Table 3).

\section{Phylogeny of Rotylenchus spp.}

The phylogenetic relationships inferred in this study based on the D2-D3 of 28S rRNA and the ITS1 of RNA gene sequences mostly agrees with morphological grouping of species obtained by the cluster analysis carried out by Castillo \& Vovlas (2005) based on key diagnostic characters of the genus Rotylenchus.

Lineage (i) with almost identical D2 and D3 expansion fragments of the LSU grouped five populations belonging to three clearly different valid species (R. goodeyi, $R$. incultus and R. laurentinus) based on morphological diagnosis (Castillo \& Vovlas 2005; Table 5). Nevertheless, all three species formed a separate cluster based on morphology and morphometry (Castillo \& Vovlas 2005). These similarities in sequences and clear incongruence in morphology have been reported in several studies in some taxa within animal kingdom. These findings have been attributed to natural selection which may force morphological evolution away from the expected correlation between morphology and phylogeny (Benton 1999; RochaOlivares et al. 2001; Renaud et al. 2007). Also, the morphological divergence could be hypothesized because of the D2-D3 of $28 \mathrm{~S}$ rRNA could be considered as rather slowly evolved marker comparing with the ITS1 for separation of some Rotylenchus species and it could not be used to detect recent speciation events. However, the ITS1 sequence data allows to distinguishing $R$. incultus and $R$. laurentinus.

Lineage (ii) includes two species (R. montanus sp. n. and Rotylenchus sp.) with similar ITS sequences and also with some common morphological characters. The single species R. unisexus formed a separate clade from all other Rotylenchus species based on D2-D3 sequences, however, the ITS1 data revealed its relationships with $R$. incultus and $R$. laurentinus. Indeed, morphologically $R$. unisexus clustered with several species including $R$. incultus, $R$. abnormecaudatus Van den Berg \& Heyns 1974 and R. devonensis Van den Berg 1976 (Castillo $\&$ Vovlas 2005).

The lineages (iv), (v) and (vi) derived from molecular data sets comprise a group of species with a long body $(>1.5 \mathrm{~mm})$, long stylets $(>40)$ and long pharyngeal overlap $(>50)$. These species groups were also noticeably distinguished in different clusters based on morphological characters (Castillo \& Vovlas 2005). Lineages (iv) and (v) included species with hemispherical lip regions of 7-8 annuli, long bodies and stylets, but the first one posses three pharyngeal gland nuclei, whereas the second one present seven pharyngeal gland nuclei; and lineage (vi) grouped two populations of a singular species with long body and stylet, but a truncate lip region, and a long pharyngeal overlap with three gland nuclei (Vovlas et al. 1998; Castillo \& Vovlas 2005). The ITS data sets clearly indicated close 
relationships between species belonging to lineages (v) and (vi).

Goodey \& Seinhorst (1960) recognized $R$. robustus (the type species of the genus) as a separate species from $R$. uniformis, based on detailed morphological studies from specimens collected near the type locality of the former (Leiden, the Netherlands). This arrangement has become generally accepted by most authors dealing with the genus (Castillo \& Vovlas 2005). Although in the present study we did not find significant molecular differences in studied D2-D3 of $28 \mathrm{~S}$ rRNA gene region for $R$. robustus and $R$. uniformis, we propose to keep a separate species status for both species until more detailed molecular research of various populations with sequences of different gene markers has been done.

Finally, lineage (vii) contains two populations from $R$. eximius, a species with a long pharyngeal overlap $(>50)$ with three gland nuclei, moderate stylet (30-35) and hemispherical lip region with four annuli which also appears separate in clusters based on morphological characters (Castillo \& Vovlas 2005). Consequently, molecular data presented in this study principally agree with previous grouping of species in the genus Rotylenchus based on morphology and morphometry (Castillo \& Vovlas 2005).

\section{Recognition of Rotylenchus jaeni comb. n. as a separate species}

Historically the manuscript with description of a new spiral nematode from Santa Elena, southern Spain was submitted to Revue de Nématologie under the name 'Rotylenchus jaeni'. After considering critical remarks of the Senior Editor (Luc 1995) and more detailed morphological analysis, authors decided to describe this nematode as a subspecies of the known species $R$. magnus Zancada 1985 . The new nematode was differentiated by minor features, such as the presence of males and the structure of the cuticle of the lip region (Luc 1995); other morphometrical and morphological diagnostic characters and ratios showed that both subspecies were practically indistinguishable (Castillo \& Vovlas 2005).

In this study in the results of analyses of the D2-D3 of $28 \mathrm{~S}$ rRNA and the ITS of rRNA gene sequences we revealed that nematodes presently known under names $R$. magnus magnus and $R$. magnus jaeni represent a separate and well-distinguishable phylogenetic lineages. The level of comparative sequence differences for two gene fragments of rRNA gene between these samples is rather significant and might consider these taxa as two valid genetic species. Thus, morphological, genetic and phylogenetic evidence can justify recognition of $R$. jaeni comb. n. as a separate species. Consequently, $R$. magnus magnus is maintained in the original rank of species (i.e. R. magnus Zancada 1985), whereas R. magnus jaeni is considered a new valid species of the genus Rotylenchus denominated as $R$. jaeni (Castillo et al. 1994) comb. n. These species are adapted to certain environmental conditions, as supported by the present distribution in Central and North, and southern Spain, respectively (Castillo \& Vovlas 2005).

The following morphological comparison of $R$. jaeni comb. n. with the closer related taxa $R$. magnus must be added: $R$. jaeni comb. n. differs essentially from the closely related species $R$. magnus by the structure of the lip area. In $R$. jaeni comb. n. in fact, the six or seven lip annuli are continuous and only the two basal annuli are divided into blocks (Fig. 8A,B), whereas in the lip region of $R$. magnus all the lip annuli (the number of which is often difficult to determine) are divided by longitudinal striae, giving a cob-like appearance of the entire lip area and no sector separation is discernible (Fig. 8E-G). Finally R. jaeni comb. n. differs from R. magnus by the relative length of the two parts of the stylet, the ' $m$ ' value being 57-63 vs. 51-55 in R. magnus, and by the shorter tail with 5-12 annuli vs. 14-19 in R. magnus. Holotype and paratype designations as well as the type specimens deposition are those referred by Castillo et al. (1994) and Luc (1995).

\section{Conclusions}

The present study suggests that the genus Rotylenchus harbours one or probably more complexes of species, which have simply diverged in morphology and rRNA gene sequences. Consequently, theses data strengthened that nematode species delimitation should be the result of integrated studies based on morphology, ecology, and genetics with the molecular taxonomic identification and phylogeny (Baker et al. 2003; Lee 2004). Future phylogenetic studies should include other additional genetic markers as mitochondrial DNA genes and nuclear protein coding genes in order to resolve the relationships within Rotylenchus and other genera of the family Hoplolaimidae. Also, a more comprehensive molecular analysis on such genetic markers based on a worldwide sample of Rotylenchus isolates may clarify which our data have been pointed out in this study.

\section{Acknowledgements}

The authors thank Dr M. Mundo-Ocampo (University of California Nematode Collection, Riverside, CA) and Dr R. Rhode (University of California Davis Collection, Davis, CA) for kindly supplying type specimens of Rotylenchus incultus and Rotylenchus unisexus for comparison, and Prof G. Bird (Michigan State University, USA) for providing $R$. robustus, and Dr N. Sasanelli (IPP-CNR, Bari) for supplying the samples of apple-orchards from Trentino. They also thank the technical assistance from J. Martín Barbarroja (IAS-CSIC). The second author acknowledges support from NSF PEET grant DEB-0731516, and the fifth author acknowledges support from Consejería de Innovación Ciencia y Empresa (CICE) of Junta de Andalucía grant P06-AGR-01360. 

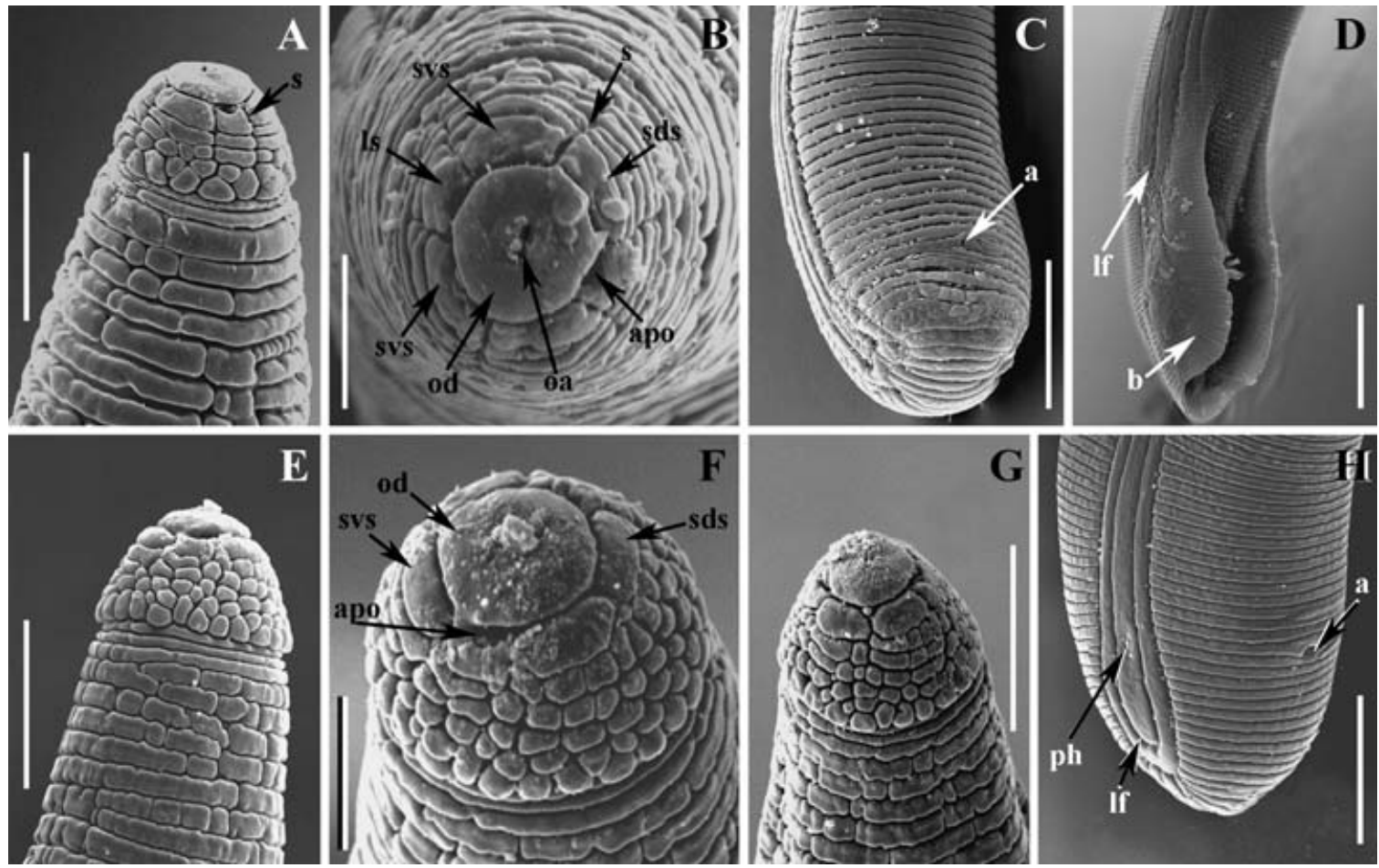

Fig. 8 A-H. Scanning electron microscope photographs of Rotylenchus jaeni (Castillo et al. 1994) comb. n. (A-D) and Rotylenchus magnus Zancada 1985 (E-H). - A. Lip region sowing longitudinal striations (s); - B. En face view showing oral aperture (oa), oral disc (od), lateral sectors (ls); - C. Female tail region showing anus (a); -D. Male tail region showing bursa (b) and lateral fields (lf). - E, G. Lip region sowing cob-like appearance. - F. En face view showing oral aperture (oa), oral disc (od), lateral sectors (ls); —H, Female tail region showing lateral fields (lf) and anus (a). (Scale bars: $\mathrm{A}, \mathrm{E}, \mathrm{G}=10 \mu \mathrm{m} ; \mathrm{B}, \mathrm{F}=5 \mu \mathrm{m} ; \mathrm{C}, \mathrm{D}, \mathrm{H}=20 \mu \mathrm{m}$ ).

\section{References}

Abolafia, J., Liebanas, G. \& Peña-Santiago, R. (2002). Nematodes of the order Rhabditida from Andalucia Oriental, Spain. The subgenus Pseudacrobeles Steiner, 1938, with description of a new species. Fournal of Nematode Morphology and Systematics, 4, 137154.

Adams, B. J. (1998). Species concepts and the evolutionary paradigm in modern Nematology. Fournal of Nematology, 30, 1-21.

Anderson, T. J. C., Blouin, M. S. \& Beech, R. N. (1998). Population biology of parasitic nematodes: applications of genetic markers. Advances in Parasitology, 41, 219-283.

Baker, C. S., Dalebout, M. L., Lavery, S. \& Ross, H. A. (2003). www.DNA-surveillance: applied molecular taxonomy for species conservation and discovery. Trends in Ecology and Evolution, 18, 271-272.

Benton, M. J. (1999). Early origins of modern birds and mammals: molecules vs. morphology. Bioessays, 21, 1043-1051.

Blouin, M. S. (2002). Molecular prospecting for cryptic species of nematodes: mitochondrial DNA versus internal transcribed spacer. International fournal for Parasitology, 32, 527-531.

Castillo, P. \& Vovlas, N. (2005). Bionomics and Identification of the Genus Rotylenchus (Nematoda: Hoplolaimidae). Leiden, Netherlands: Brill Academic Publishers, pp. 377.
Castillo, P., Vovlas, N., Gómez Barcina, A. \& Lamberti, F. (1994). The plant parasitic nematode Rotylenchus (a monograph). Nematologia Mediterranea, 21 (Suppl.), 200, pp.

Castillo, P., Vovlas, N., Subbotin, S. \& Troccoli, A. (2003). A new root-knot nematode, Meloidogyne baetica n. sp. (Nematoda: Heteroderidae), parasitizing wild olive in Southern Spain. Phytopathology, 93, 1093-1102.

Chen, D. Y., Ni, H. F., Chen, R. S., Yen, J. H. \& Tsay, T. T. (2006). [Identification of spiral nematode (Nematoda: Rotylenchinae) collected from Taiwan and Kinmen.]. Plant Pathology Bulletin, 15, 153-169.

Coolen, W. A. (1979). Methods for extraction of Meloidogyne spp. \& other nematodes from roots and soil. In F. Lamberti \& C. E. Taylor (Eds) Root-Knot Nematodes (Meloidogyne Species). Systematics, Biology, and Control (pp. 317-329). London, UK: Academic Press. Goodey, J. B. \& Seinhorst, J. W. (1960). Further observations and comments on the identity of Rotylenchus robustus (De Man, 1876) Filip'ev, 1934 with a description of a proposed neotype and a new definition of Rotylencbus goodeyi. Nematologica, 5, 136-148.

Han, K., Lee, Y. \& Kim, W. (2002). PseudoViewer: automatic visualization of RNA pseudoknots. Bioinformatics, 18 (Suppl. 1), S321-S328.

Huelsenbeck, J. P. \& Ronquist, F. (2001). MrBAYES: Bayesian inference of phylogenetic trees. Bioinformatics, 17, 754-755. 
Lee, M. S. Y. (2004). The molecularisation of taxonomy. Invertebrate Systematics, 18, 1-6.

Luc, M. (1995). On Rotylenchus magnus jaeni Castillo et al., 1994 (Nemata: Hoplolaimidae). Fundamental and Applied Nematology, 18, 307-308.

Nadler, S. A. (2002). Species delimitation and nematode biodiversity: phylogenies rule. Nematology, 4, 615-625.

Nicholas, K. B., Nicholas, H. B. Jr \& Deerfield, D. W. I. I. (1997). GenDoc: analysis and visualization of genetic variation. EMBNEW NEWS, 4, 14.

Oliveira, C. M. G., Ferraz, L. C. C. B. \& Nelson, R. (2006). Xiphinema krugi, species complex or complex of cryptic species? Fournal of Nematology, 38, 418-428.

Renaud, S., Chevret, P. \& Michaux, J. (2007). Morphological vs. molecular evolution: ecology and phylogeny, both shape the mandible of rodents. Zoologica Scripta, 36, 525-535.

Rocha-Olivares, A., Fleeger, J. W. \& Foltz, D. W. (2001). Decoupling of molecular and morphological evolution in deep lineages of a meiobenthic harpacticoid copepod. Molecular Biology and Evolution, 18, 1088-1102.

Ronquist, F. \& Huelsenbeck, J. P. (2005). Bayesian analysis of molecular evolution using MRBAYEs. In R. Nielsen (Ed.) Statistical Methods in Molecular Evolution. New York: Springer.

Scotto La Massèse, C. \& Germani, G. (2000). Description de quatre nouvelles espèces et de quatre populations de Rotylenchus (Nematoda: Hoplolaimidae). Proposition d'une clé tabulaire. Nematology, 2, 699-718.

Seinhorst, J. W. (1966). Killing nematodes for taxonomic study with hot f.a. 4: 1. Nematologica, 12, 178.

Siddiqi, M. R. (2000). Tylenchida Parasites of Plants and Insects. Wallingford, UK: CABI Publishing.

Siebert, S. \& Backofen, R. (2005). MARNA: multiple alignment and consensus structure prediction of RNAs based on sequence structure comparisons. Bioinformatics, 21, 3352-3359.

Subbotin, S. A. \& Moens, M. (2006). Molecular taxonomy and phylogeny. In R. Perry \& M. Moens (Eds) Plant Nematology (pp. 33-58). Wallingford, UK: CABI.

Subbotin, S. A., Sturhan, D., Rumpenhorst, H.J. \& Moens, M. (2003). Molecular and morphological characterisation of the Heterodera avenae complex species (Tylenchida: Heteroderidae). Nematology, $5,515-538$.
Subbotin, S. A., Sturhan, D., Chizhov, V. N., Vovlas, N. \& Baldwin, J. G. (2006). Phylogenetic analysis of Tylenchida Thorne, 1949 as inferred from D2 and D3 expansion fragments of the 28S rRNA gene sequences. Nematology, 8, 455-474.

Subbotin, S. A., Sturhan, D., Vovlas, N., Castillo, P., Tanyi Tambe, J., Moens, M. \& Baldwin, J. G. (2007). Application of the secondary structure model of rRNA for phylogeny: D2-D3 expansion segments of the LSU gene of plant-parasitic nematodes from the family Hoplolaimidae Filipjev, 1934. Molecular Phylogenetics and Evolution, 43, 881-890.

Swofford, D. L. (2003). PAUP*: Phylogenetic Analysis Using Parsimony (*and Other Methods), Version 4.0b 10. Sunderland, Massachusetts: Sinauer Associates.

Tandingan De Ley, I., Mundo-Ocampo, M., Yoder, M. \& De Ley, P. (2007). Nematodes from vernal pools in the Santa Rosa Plateau Ecological Reserve, California I. Hirschmanniella santarosae sp. $\mathrm{n}$. (Nematoda: Pratylenchidae), a cryptic sibling species of $H$. pomponiensis Abdel-Rahman Maggenti, 1987. Nematology, 9, 405429.

Thompson, J. D., Gibson, T. J., Plewniak, F., Jeanmougin, F. \& Higgins, D. G. (1997). The ClustalX windows interface: flexible strategies for multiple sequence alignment aided by quality analysis tools. Nucleic Acids Research, 25, 4876-4882.

Vandamme, P., Pot, B., Gillis, M., de Vos, P., Kersters, K. \& Swings. J. (1996). Polyphasic taxonomy, a consensus approach to bacterial systematics. Microbiolological Review, 60, 407-438.

Vovlas, N., Cham, S. \& Hooper, D. J. (1980). Observations on the morphology and histopathology of Rotylenchus laurentinus attacking carrots in Italy. Nematologica, 26, 302-307.

Vovlas, N., Troccoli, A., Castillo, P. (1998). Observations on the polinucleate esophageal glands of Rotylenchus magnus jaeni Castillo et al., 1994 juveniles with comments on the morphology of a population of R. agnetis Szczygiel, 1968 from Italy. Nematropica, $28,231-240$.

Ye, W. Szalanski, A. L. \& Robbins, R. T. (2004). Phylogenetic relationships and genetic variation in Longidorus and Xiphinema species (Nematoda: Longidoridae) using ITS1 sequences of nuclear ribosomal DNA. Fournal of Nematology, 36, 14-19.

Zuker, M. (1989). On finding all suboptimal folding of an RNA molecule. Science, 244, 48-54. 